\title{
AN UPDATE ON COLOR IN GEMS. PART 3: COLORS CAUSED BY BAND GAPS AND PHYSICAL PHENOMENA
}

\author{
By Emmanuel Fritsch and George R. Rossman
}

The previous two articles in this series described the origins of color in gems that derive from isolated structures of atomic dimensions - an atom (chromium in emerald), a small molecule (the carbonate group in Maxixe beryl), or particular groupings of atoms $\left(\mathrm{Fe}^{2+}-\mathrm{O}-\mathrm{Fe}^{3+}\right.$ units in cordierite). The final part of this series is concerned with colors explained by band theory, such as canary yellow diamonds, or by physical optics, such as play-of-color in opal. In the case of band theory, the color-causing entity is the very structure of the entire crystal; in the case of physical phenomena, it is of microscopic dimension, but considerably larger than the clusters of a few atoms previously discussed.

\section{ABOUT THE AUTHORS}

Dr. Fritsch is research scientist at the Gemological Institute ol America, Santa Monica, Calilornia Dr. Rossman is prolessor of mineralogy at the California Institute of Technology, Pasadena, CaliIornia.

Acknowledgments: E. F. wishes to thank Professor Georges Calas, Mr. Pierre Bariand, and Ms. Anne Voileau for their help and encouragement in writing the original French version of this article. Special appreciation goes to Ms. Pat Gray for typing the original English manuscripl and improving the transtation, and to Ms. Ruth Patchick for word processing the many revisions, especially the tables. The authors are also grateful to Ms. Laurel Bartlell, Dr. James Shigley, Mr. John Koivula, and Dr. John Hummel for their constructive comments. (c) 1988 Gemological Instilute of America
A 11 of the colors discussed in parts 1 and 2 of this series A(Fritsch and Rossman, 1987 and 1988) arise from processes in which electrons are localized on a single atom or are delocalized over no more than a few atoms. The colors that arise from these processes depend on the presence of specific mipor components or defects in the host crystal. However, colors can arise, though less commonly, from processes that involve the entire crystal, through either its electronic structure (band theory) or its internal texture (physical phenomena such as interference effects, diffraction effects, scattering, and inclusions; see figure 1). These, the most unusual causes of color in gems, are covered in this last article of our series.

\section{BAND THEORY}

In contrast to the processes described in the first two parts of this series, the electrons in some gem minerals can be delocalized over the entire crystal, and produce color through their interaction with visible light. Such delocalization is a characteristic property of most metals and semiconductors. The physical theory that describes the cause of color in such materials is called band theory. Examples of the various gem colors explained by this theory are presented in table 1.

In numerous solid materials, billions of atoms contribute to the possible energy levels, which are so numerous and so close together that they are considered collectively as an energy band. This is of particular interest in the case of some semiconducting and metallic minerals (Marfunin, 1979a). There are two bands in these solids: a low-energy valence band that is fully populated with electrons, and a high-energy conduction band that is generally empty (figure 2). The energy that separates these bands is well defined and is called a "band gap." This energy separation is of dramatic importance to the optical properties of certain types of gemstones. 


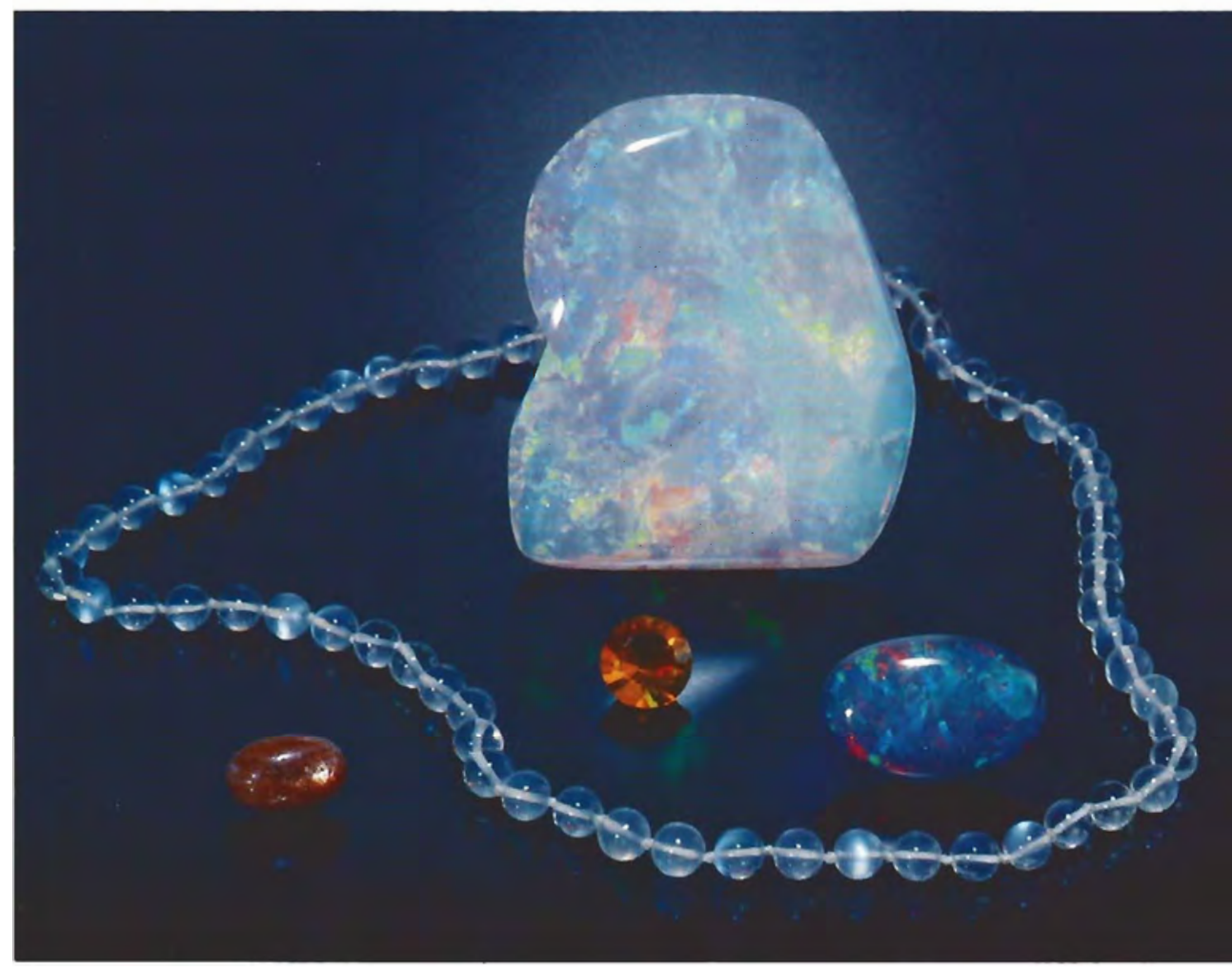

Figure 1. Colors in gem materials can be caused by a wide variety of processes. This article explains color-producing mechanisms related to band theory and physical phenomena. Examples of the latter include diffraction in opal (in the center top and bottom right), scattering of light in "moonstone" feldspar (the necklace), and coloration by inclusions in fire opal (center bottom) and "sunstone" feldspar (bottom left). The necklace is courtesy of Elise Misiorowski; photo by Robert Weldon.

For these gemstones, transitions between bands rather than between energy levels of single atoms are responsible for the color. These "interband transitions" occur when electrons from the valence band receive sufficient energy by absorbing light to "jump" over the band gap and reach the conduction band. As illustrated in figure 2, three different scenarios are possible for interband transitions.
When the energy of the band gap is greater than the maximum energy of the visible range (i.e., the violet light), visible light does not supply enough energy to cause an electron to jump from the lower band to the upper one (figure 2A). Consequently, all of the visible spectrum is transmitted (none is absorbed and, in the absence of impurities or defects, the mineral is colorless. Such materials e.g., corundum, beryl, quartz, diamond, and topaz,

TABLE 1. Types of gem materials for which color can be explained by the band theory and examples of the colors produced.

\begin{tabular}{|c|c|c|c|}
\hline Origin of color & Type of material & Color & Examples \\
\hline \multirow[t]{3}{*}{$\begin{array}{l}\text { Band gap less than the } \\
\text { energy of visible light }\end{array}$} & \multirow[t]{3}{*}{$\begin{array}{l}\text { Conductors and some } \\
\text { semiconductors = colored opaque } \\
\text { materials with metallic luster }\end{array}$} & $\begin{array}{l}\text { Violet to blue } \\
\text { Yellow }\end{array}$ & $\begin{array}{l}\text { Covellite (Berry and Vaughan, 1985) } \\
\text { Gold, pyrite (Nassau, 1975; } \\
\text { Fritsch, 1985) }\end{array}$ \\
\hline & & Red & Copper (Nassau, 1975) \\
\hline & & White & Silver, platinum (Nassau, 1975) \\
\hline $\begin{array}{l}\text { Band gap in the } \\
\text { visible range }\end{array}$ & Some semiconductors & Red & Cuprite, cinnabar (Fritsch, 1985) \\
\hline $\begin{array}{l}\text { Band gap greater than the } \\
\text { energy of visible light }\end{array}$ & $\begin{array}{l}\text { Some semiconductors and all } \\
\text { insulators }\end{array}$ & $\begin{array}{l}\text { Intrinsically } \\
\text { colorless }\end{array}$ & $\begin{array}{l}\text { Diamond, corundum, beryl, quartz, } \\
\text { lopaz, fluorite (Fritsch, 1985) }\end{array}$ \\
\hline \multirow[t]{2}{*}{$\begin{array}{l}\text { Color modified by minor } \\
\text { components }\end{array}$} & \multirow[t]{2}{*}{ Some semiconductors } & Blue & $\begin{array}{l}\text { Type Ilb diamond, containing } \\
\text { dispersed boron atoms (Collins, } \\
\text { 1982) }\end{array}$ \\
\hline & & Yellow & $\begin{array}{l}\text { Type Ib diamond, containing } \\
\text { dispersed nitrogen atoms (Collins, } \\
\text { 1982) }\end{array}$ \\
\hline
\end{tabular}


as well as many other oxides and silicates-are inherently electrical insulators.

When the energy of the gap is less than the energy of violet light (i.e., is in the visible range), the most energetic radiations in the visible range (violet to blue to green) are absorbed, leaving the low-energy range unaffected, that is, transmitted (figure 2B). The exact energy of the band gap varies among different materials, so the transmitted color will also vary. Usually band-gap colors range from deep yellow to deep red. Cuprite and cinnabar (figure 3) are colored red by such a process.

The energy in the band gap may be even less than the lowest energy of the visible spectrum (red). In such a situation, all wavelengths of visible light will cause a transition from the valence band to the conduction band, so the whole visible spectrum is absorbed (figure $2 \mathrm{C}$ ). As a conse- quence, the mineral usually appears black and opaque. All metals have just such a small band gap or no band gap at all. They appear, however, to be shiny (metallic luster) because their electrons quickly return to their original energy level, emitting the exact same energy (light) that they formerly absorbed (Nassau, 1975b). In some metals, the number of available excited states may vary throughout the conduction band, so that some wavelengths are absorbed and re-emitted more efficiently than others, thus producing color. Although silver and platinum absorb and emit all wavelengths with about the same efficiency and appear white, gold (or pyrite) absorbs and emits more yellow than the other wavelengths and so gets its distinct golden coloration (again, see figure 3).

The band gaps discussed thus far are an intrin-

$$
\text { . }
$$

Figure 2. The three possible types of intrinsic coloration of gem materials are explained by examining the width of the band gap in relation to the visible range. (A) Band gap greater than the energy of the visible range: All visible radiation is transmitted and the gem is intrinsically colorless. (B) Band gap in the visible range: Only the high-energy part of the spectrum (violet to blue to green) is absorbed, and the gem is yellow to red. (C) Band gap less than the energy of visible light: All visible radiation is absorbed and the material is black, or displays metallic colors due to re-emission. Artwork by Jan Newell

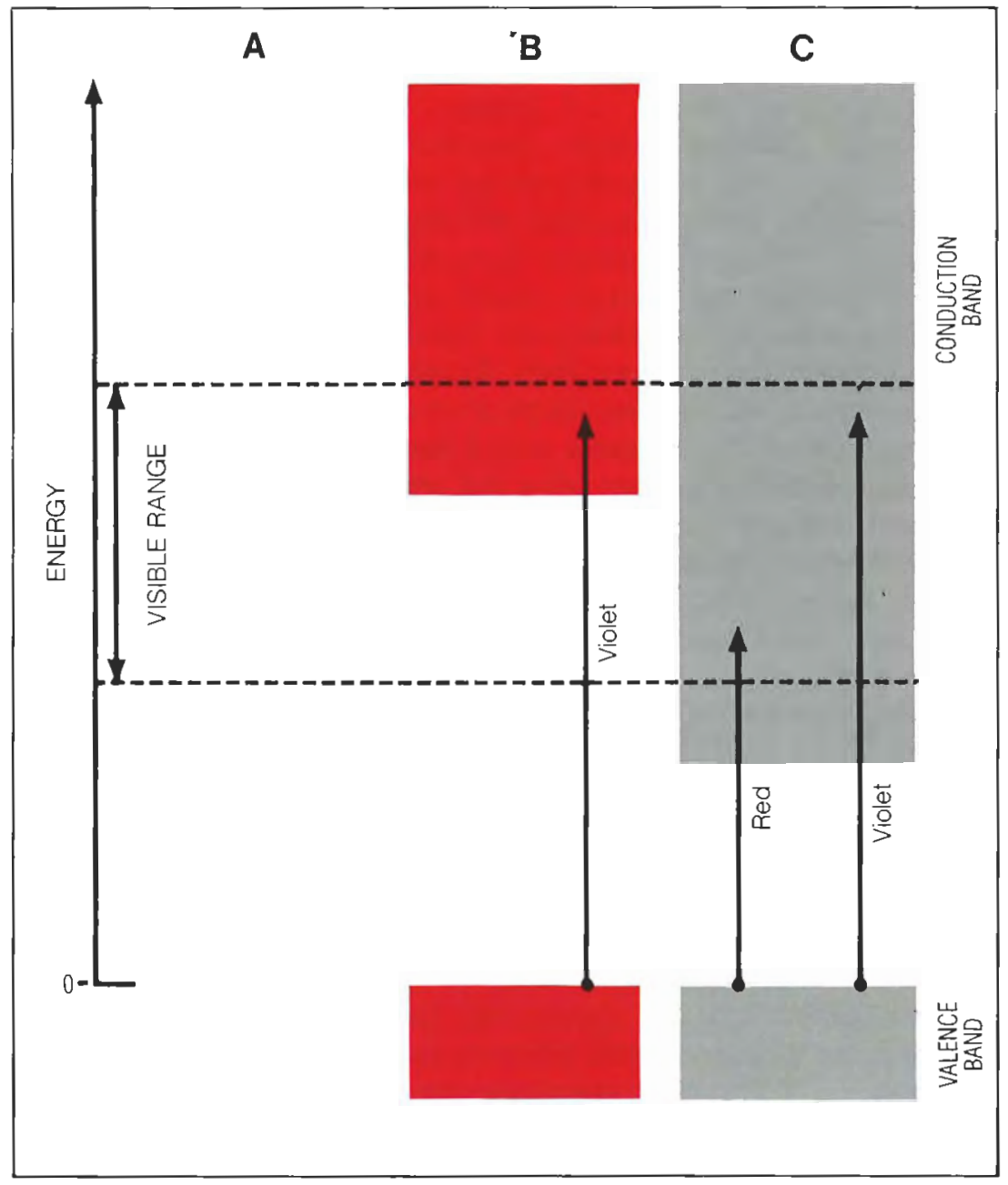




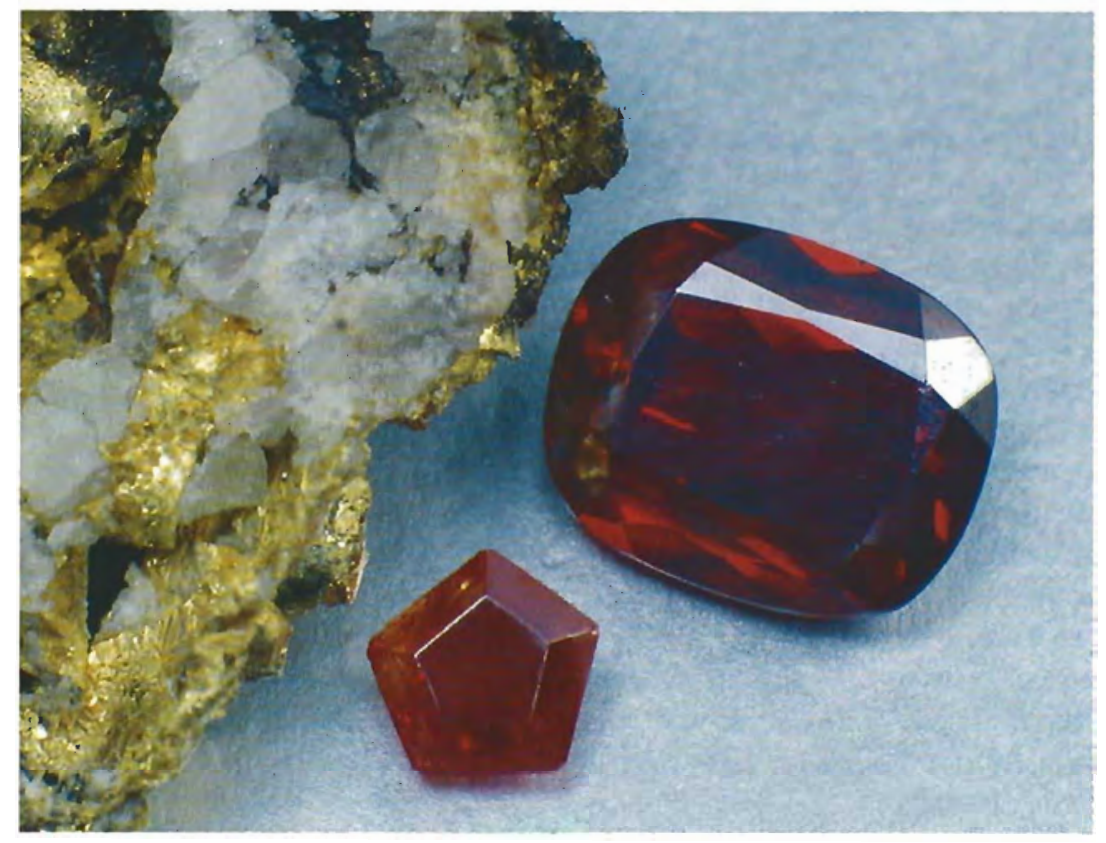

Figure 3. The red color of cuprite (the cushion cut) and cinnabar (the pentagon cut) has little to do with the fact that these gems contain copper and mercury, respectively. The color occurs because the band gap of these minerals is within the visible range: All wavelengths from violet to orange are absorbed, so that only red light is transmitted. The band gap in gold is much smaller than the energy of the visible range: All visible light is absorbed but some wavelengths are reemitted preferentially, giving gold its yellow color and metallic luster. (Remember that the energy scale is inverse to the wavelength scale.) Photo by Robert Weldon.

sic property of the material; they are ultimately directly related to its chemical composition and atomic structure. In some semiconductors, however, color is caused by small amounts of impurity atoms that normally do not produce color in intrinsically colorless minerals. Specifically, these atoms can introduce electronic energy levels at an energy between the valence band and the conduction band of the host mineral (see figure 4). Some of the most striking examples are canary yellow and fancy blue diamonds, which contain isolated nitrogen and boron atoms, respectively. Although pure (colorless) diamonds are insulators, they may also be considered semiconductors with a band gap so large that they have neither color nor appreciable electrical conductivity (figure 4A). Nitrogen can easily substitute for carbon, which it follows in the periodic table of elements. Because nitrogen possesses one more electron than carbon, however, it becomes an electron "donor" when it substitutes for carbon in diamond. This additional electron contributes an additional energy level situated above the diamond valence band, but below the diamond conduction band (figure 4B). However, because this donor level has a finite width, light of a variety of wavelengths extending from the ultraviolet into the visible range up to $560 \mathrm{~nm}$ (green) will be absorbed, creating a strong yellow color. This type of coloration occurs only in type $\mathrm{Ib}$ diamonds, in which isolated nitrogen atoms substitute for carbon atoms in the proportion of about 1 to 100,000 (Collins, 1982). This color is distinct from the yellow color commonly caused by the nitrogen-related N3 color center, which produces the familiar Cape series of absorption lines.

Boron has one less electron than carbon, which follows it in the periodic table of elements. Therefore, boron is an electron "acceptor" when substituting for carbon in diamond. It contributes its own electron energy band, which is situated within the diamond band gap (figure 4C). The excitation of an electron from the diamond valence band to the acceptor level requires only a very low energy, in the infrared range (Collins, 1982). Because the boron energy band is broad, it can cause absorption extending from the infrared up to 500

Figure 4. The band gap in pure diamond is much greater than the visible range (A), so this gem is intrinsically colorless. However, a substitutional nitrogen atom introduces a level that donates electrons to the diamond conduction band $(B)$, creating an absorption in the ultraviolet that extends into the blue end of the visible range (see spectrum); such stones are of an intense yellow color, and are therefore called "canary" (type Ib) diamonds. By contrast, a boron atom substituting for carbon can introduce a broad energy level available for electrons from the diamond valence band (C), which will induce an absorption of the near-infrared and the red end of the visible range (see spectrum), giving a blue hue to such a stone (type IIb diamond). These three mechanisms are illustrated by the colorless, De Beers synthetic type Ib yellow (photo (C) Tino Hammid), and natural dark blue diamonds shown here. Artwork by lan Newell. 


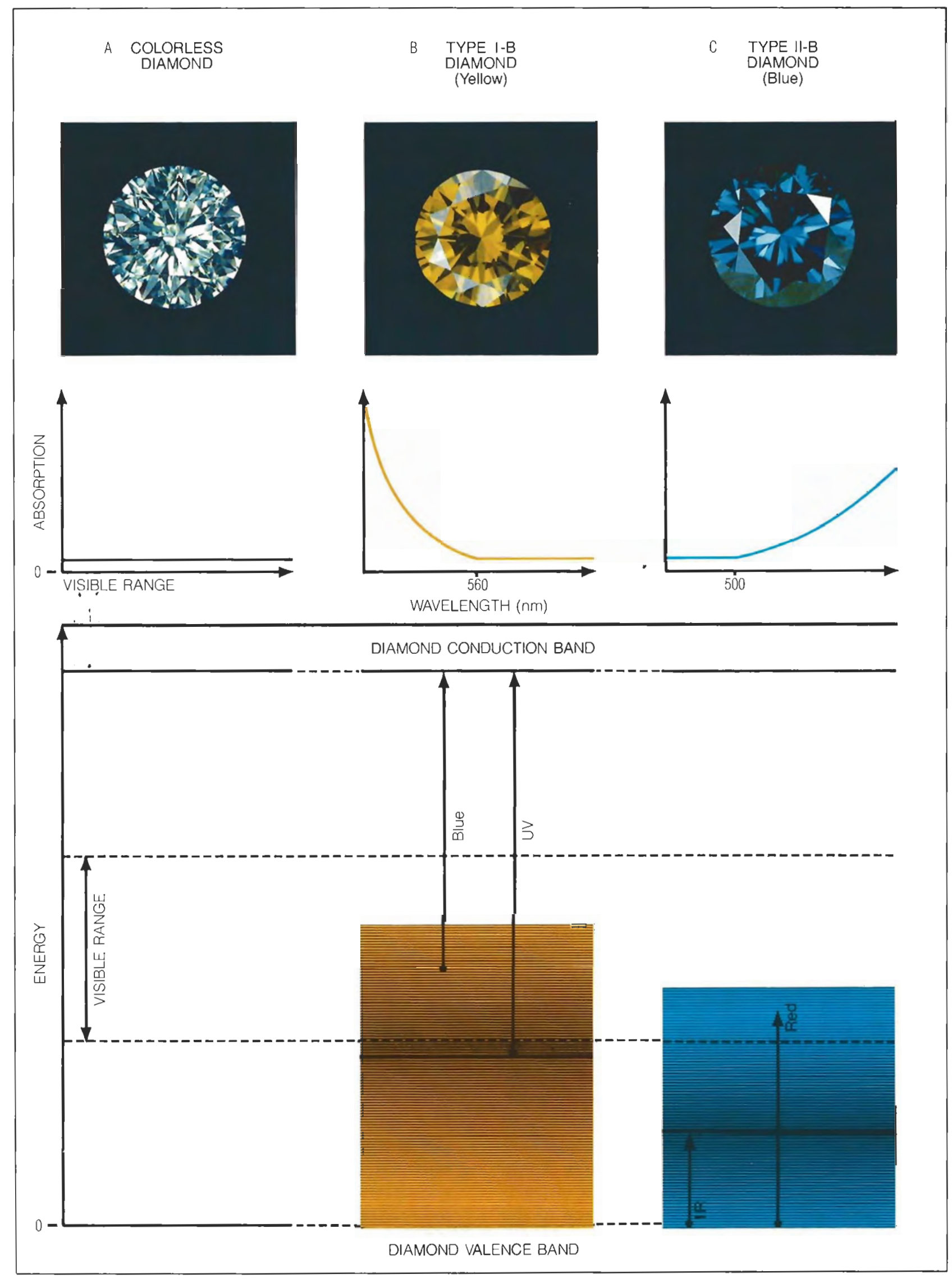




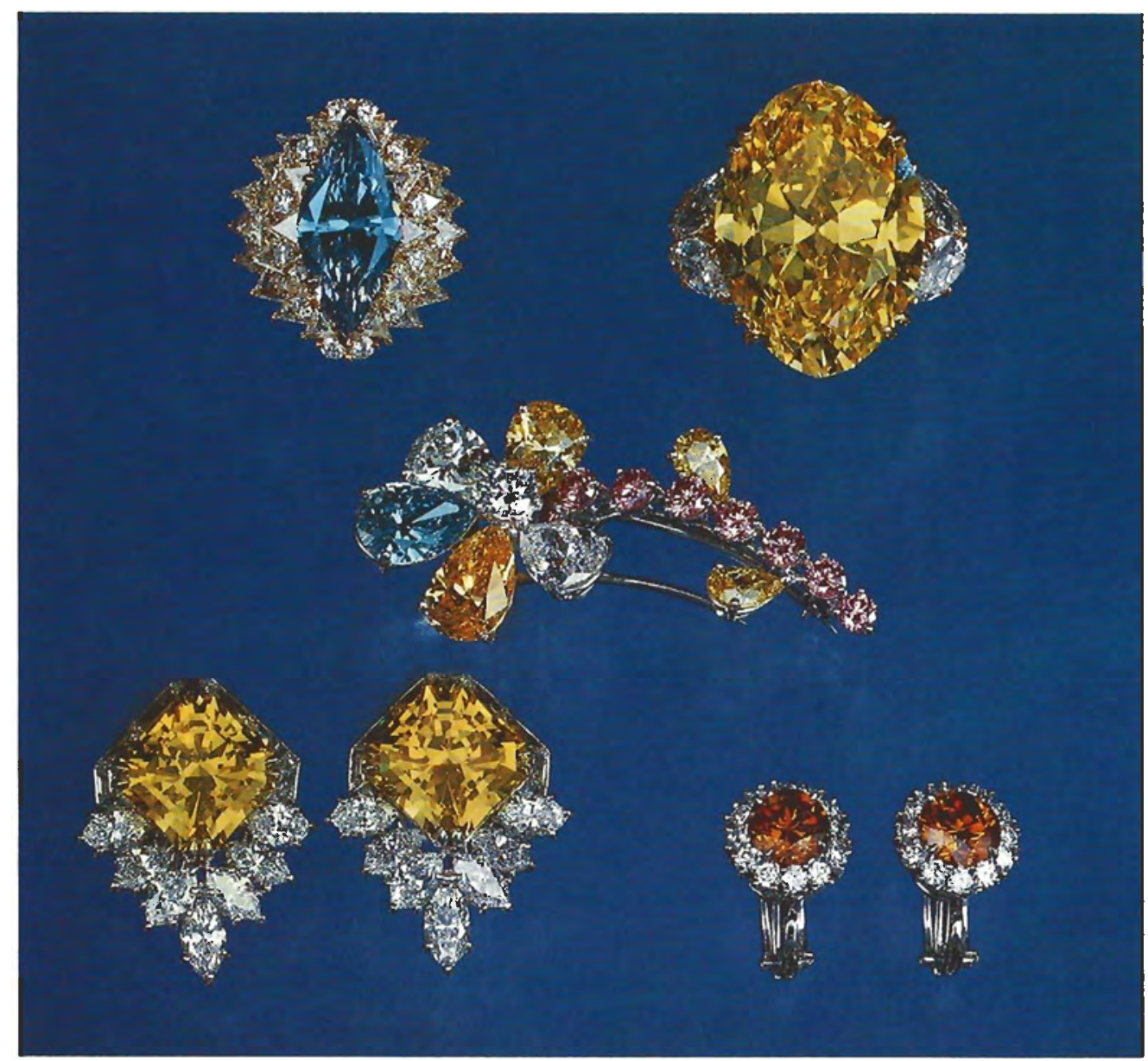

Figure 5. Minute

amounts of boron contribute the intense blue color to blue diamonds. Yellow in diamonds can arise from a variety of processes, all of which are related to the presence of nitrogen impurities. The possible origins of color for orange, brown, and pink diamonds are listed in table 4. The blue marquise shown here is $3.88 \mathrm{ct}$; the intense yellow oval weighs $29.16 \mathrm{cts}$; the two intense yellow diamonds mounted in earrings weigh a total of $12.26 \mathrm{ct}$. Jewelry courtesy of Harry Winston, Inc.; photo (C) Harold E Erica Van Pelt.

$\mathrm{nm}$ (the edge of the green). The resulting blue color, which can be produced with boron concentrations as low as one part per million (Nassau, 1975b), may be quite intense (figure 5). The Hope diamond is the most famous example of a blue diamond. There is no known commercial treatment that would affect band-gap coloration.

\section{COLORS THAT ARISE FROM PHYSICAL PHENOMENA}

All of the colors discussed thus far in this series have been due to the absorption of light. But as the introduction to part 1 pointed out, other causes of color are possible. In some gem materials, physical properties such as inclusions or lamellar texture can influence the hue. In this next section, we will explore how light interference, diffraction, and scattering can interact with these physical features to create colors in gem materials. These processes are rarely related directly to the chemistry of the stone, but rather are connected to the texture or internal arrangement of the mineral. The various colors obtained in gems as a conse- quence of physical phenomena are summarized in table 2 .

Interference Effects from Thin Films. Interference phenomena occur when two rays of light travel along the same path or in closely spaced parallel paths. If these rays, or light waves, vibrate in phase, the wave crests reinforce each other to produce bright light (constructive interference). If the light waves vibrate exactly out of phase, they cancel each other to produce darkness (destructive interference).

Iridescence, the most common interference phenomenon, occurs when light passes through a thin transparent film that has a different index of refraction from the surrounding medium (e.g., a thin film of air in "iris quartz"). Rays reflected from the bottom of the film will travel beside waves reflected from the top of the film. At certain wavelengths, dictated by the thickness and the index of refraction of the film, the rays vibrate out of phase and the corresponding colors are removed from the reflected light through destructive inter- 
ference. The remaining wavelengths produce the familiar colored effects that appear when a drop of oil expands as a thin film on water. The possible colors in iridescence are illustrated in figure 6 . None of these colors is a pure spectral color.

In gemology, examples can be found as interference color in cracks (again, "iris quartz"), or in tarnish films on oxidized cut stones and sulfide crystals, such as pyrite and bornite (Nassau, 1975b|. Iridescent cracks are sometimes created by heating and rapidly cooling a stone ("quench crackling'), especially quartz. The color observed in many pearls is also due in part to interference effects (again, see figure 6). Pearls are constructed from concentric alternating layers of aragonite and conchiolin, two substances of different refractive indices. Incoming overhead light is reflected from the surfaces between those successive layers. The reflected light interferes with the incoming light to create delicate iridescent colors, called orient. Mother-of-pearl and some abalone pearls exhibit similar interference effects, but the colors generally are stronger and less subtle (figure 7). In addition" to "quench crackling," interference effects can a'lso be generated by coating thin films of various substances on the surface of a gem.

Diffraction Effects. Diffraction effects are special types of interference phenomena. The most important of these for gem materials is that caused by a regular stacking of alternating layers that have different indices of refraction. This diffraction effect produces pure spectral colors, in contrast to iridescence, which gives rise to colors that are a combination of several spectral colors (again, see figure 6).

Opal is one of the very few gems that can exhibit all colors of the spectrum in a single stone. It is interesting to note in play-of-color opal that although the pattern may be quite irregular, within each color region the color is homogeneous (see, for example, figure 1 of this article and the cover of this issue). The color of any one patch depends on the orientation of the overhead light source; when the stone moves, the color changes, giving "life" to the opal. If the light emerging from one of the color patches is analyzed, it appears to be a pure spectral color, that is, essentially of only one wavelength. These properties are characteristic of the diffraction effect created by the interaction of white light with a regularly layered structure (figure 8).
TABLE 2. Physical phenomena and examples of the colors they cause in various gem materials.

\begin{tabular}{|c|c|}
\hline Process & $\begin{array}{l}\text { Color and } \\
\text { gem material }\end{array}$ \\
\hline $\begin{array}{l}\text { Interference } \\
\text { on a thin film }\end{array}$ & $\begin{array}{l}\text { Various (nonspectral) colors: iris quartz, } \\
\text { iridescent coatings and tarnish, "orient" in } \\
\text { pearls, mother-of-pearl (Nassau, 1975) }\end{array}$ \\
\hline Diffraction & $\begin{array}{l}\text { All (spectral) colors: play-of-color opal } \\
\text { (Darragh and Sanders, } 1965), \\
\text { labradorite/spectrolite (Ribbe, 1972), } \\
\text { some rare andradites (Hirai and Nakazawa, } \\
\text { 1982) }\end{array}$ \\
\hline \multicolumn{2}{|l|}{ Scattering } \\
\hline $\begin{array}{l}\text { Rayleigh } \\
\text { scattering }\end{array}$ & $\begin{array}{l}\text { Blue: feldspar/moonstone (Lehmann, } \\
\text { 1978), some blue quartz (Zolensky et al., } \\
\text { 1988), some opal (Lehmann, 1978) }\end{array}$ \\
\hline \multirow[t]{2}{*}{ Mie scattering } & $\begin{array}{l}\text { Violet: fluorite, scattering by calcium } \\
\text { microcrystals (Braithwaite et al., 1973) }\end{array}$ \\
\hline & $\begin{array}{l}\text { Red: ruby glass, scattering by copper } \\
\text { or gold microcrystals (Nassau, 1983) }\end{array}$ \\
\hline $\begin{array}{l}\text { Scattering } \\
\text { from structures } \\
\text { larger than } \\
\text { visible } \\
\text { wavelengths }\end{array}$ & White: milky quartz (Fritsch, 1985) \\
\hline \multirow{4}{*}{$\begin{array}{l}\text { Presence of } \\
\text { colored } \\
\text { inclusions }\end{array}$} & $\begin{array}{l}\text { Blue: dumortierite inclusions in quartz } \\
\text { (J. Koivula, pers. comm., 1988) }\end{array}$ \\
\hline & $\begin{array}{l}\text { Green: nickel-bearing clays in } \\
\text { chrysoprase and prase opal (A. Manceau, } \\
\text { pers. comm., 1987; Koivula and Fryer, } \\
\text { 1984), chromian mica (fuchsite) in } \\
\text { aventurine quartz (Lehmann, 1978) }\end{array}$ \\
\hline & $\begin{array}{l}\text { Orange: hydrous iron oxides in carnetian } \\
\text { agate and fire opal (J. Koivula, pers. } \\
\text { comm., 1988) }\end{array}$ \\
\hline & $\begin{array}{l}\text { Red: hematite platelets in orthoclase } \\
\text { (Andersen, 1915), hematite or copper } \\
\text { platelets in sunstone feidspar (Lehmann, } \\
\text { 1978), cordierite/"bloodshot iolite" (Gübelin } \\
\text { and Koivula, 1987) }\end{array}$ \\
\hline
\end{tabular}

The structure of opal was first revealed with scanning electron microscopy more than 20 years ago (Darragh and Sanders, 1965). It is an extraordinarily regular stacking of parallel layers of small spheres composed of hydrous silica. Color phenomena occur when the diameter of these spheres is less than the wavelengths of visible light. The conditions for diffraction of a given color are met when the distance between two successive layers is approximately equal to the wavelength of that color divided by the index of refraction of the spheres. The exact conditions are described in Nassau (1983). Consequently, the diffracted wavelength is proportional to the size of the particle. For example, the intense red is selected by spheres of about $250 \mathrm{~nm}$ in diameter (Darragh and Sanders, 

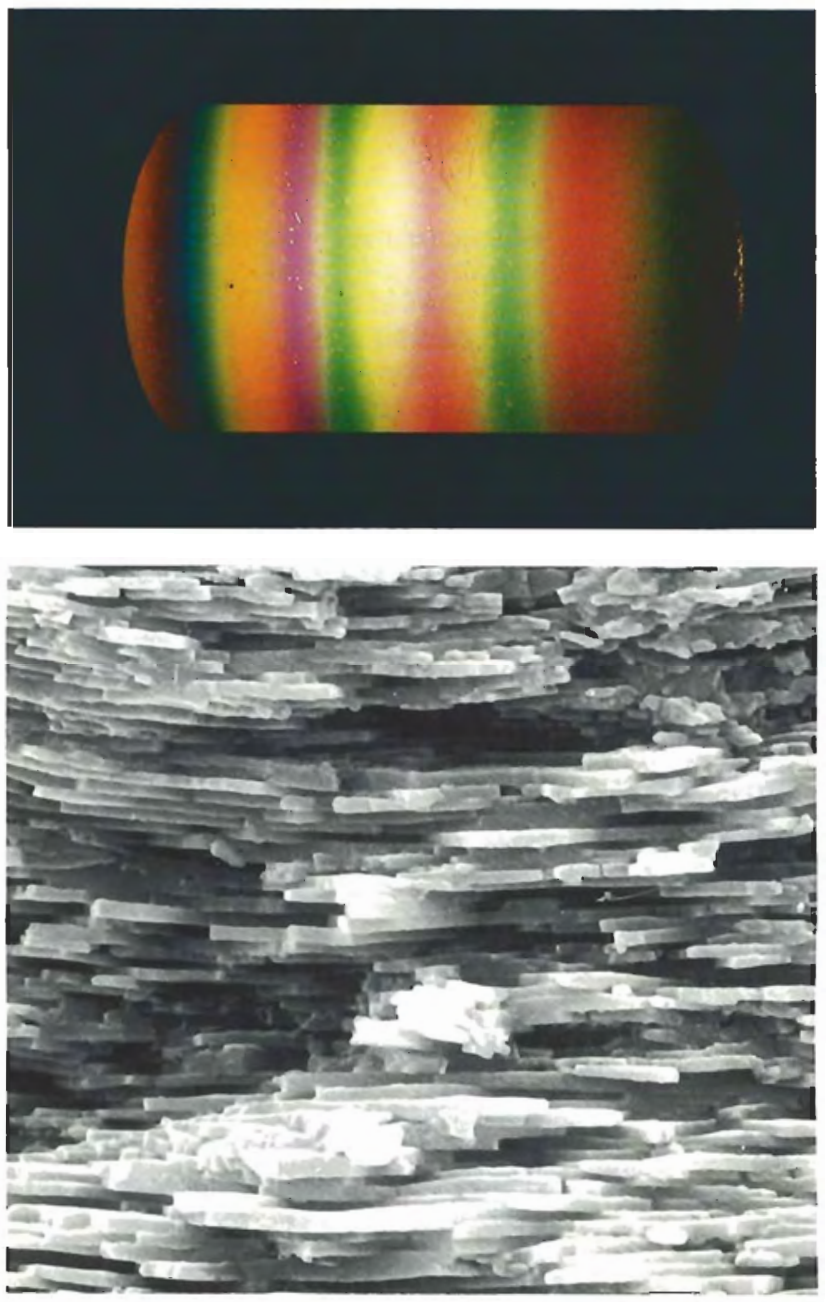

1965). The other colors are diffracted by smaller spheres, down to $140 \mathrm{~nm}$ in diameter.

As stated earlier, the color of the diffracted light varies with the angle between the direction of illumination and the direction of observation. The observed wavelength is at a maximum (e.g., red) when those two directions are perpendicular. When the stone is rocked away from this position, the observed wavelength decreases (e.g., goes to orange; Lehmann, 1978).

For the more commonplace play-of-color opals, those with mostly blue and green patches, the remainder of the incoming light (i.e., yellow to red) is transmitted so that an orange coloration is seen in transmitted light. Fire opal, however, probably owes its yellow-to-red body color (figure 9) to both diffraction and body absorption by $\mathrm{Fe}^{3+}$-rich submicroscopic to microscopic inclusions between the silica spheres (J. Koivula, pers. comm., 1988).

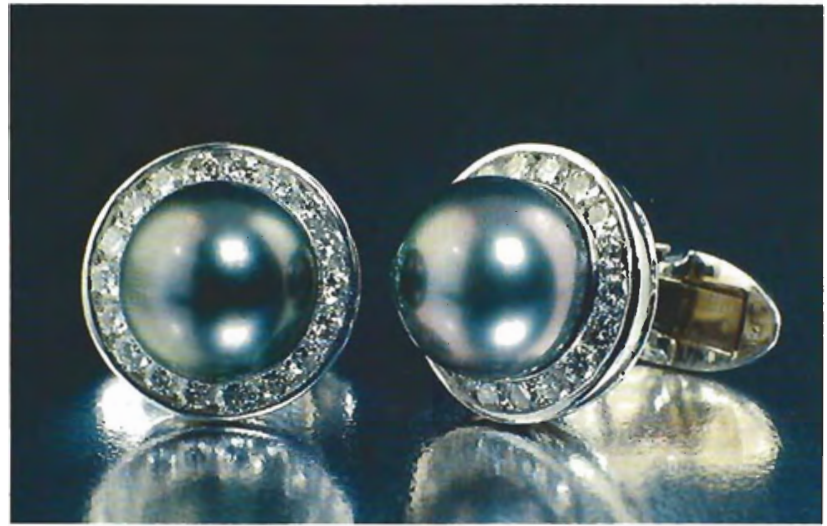

Figure 6. The colors produced by interference on a thin film are the same as those observed on this quartz wedge (top left) in polarized light. None of them is a pure spectral color. Notice that the "higher orders" on the right produce mostly pink and green. Interference colors are caused in pearls by light passing through and reflected back by alternating concentric layers of aragonite and conchiolin, which are readily visible on the electron photomicrograph of a pearl section (left). The resulting "high order" interference colors (mostly green and pink) are called orient and overtone (the latter, when they are stronger and homogeneous all over the pearl). They are readily apparent in these black pearl cufflinks (top right). Photomicrograph courtesy of B. Lasnier, Gemology Laboratory, Nantes University, France. Jewelry courtesy of Harry Winston, Inc. Color photos by Robert Weldon.

Similar effects are encountered in some feldspars belonging to the plagioclase series. These feldspars display regions of color, often violet to green, against a generally black background. Fínnish "Spectrolite," a variety of labradorite, appears to show every color of the spectrum. This phenomenon is called "labradorescence," after the classic occurrence of these stones on the Isle of Paul, Labrador, although varieties of plagioclase feldspars other than labradorite may display this effect. The diffracting objects in labradorescence are alternating layers, known as exsolution lamellae, of two feldspars with different chemical compositions. One layer is calcium rich and the other is calcium poor. The color created by the lamellar structures depends on their respective thicknesses and indices of refraction (figure 10). Another gemstone that occasionally shows diffraction colors is andradite from Hermosillo, Mexico 


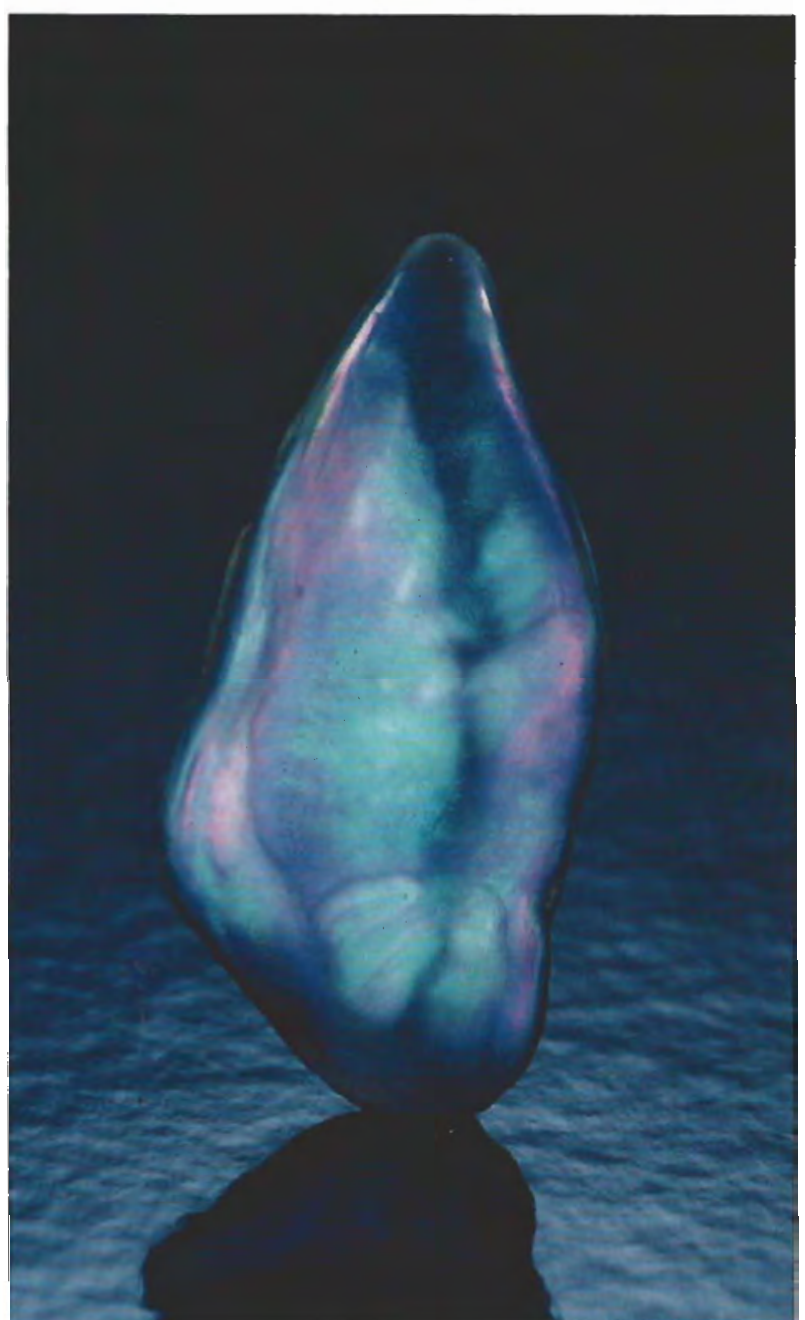

Figure 7. Pink and green interference colors make a spectacular display in this abalone pearl. Courtesy of Lowell Jones, St. Louis, MO; photo (c) Tino Hammid.

(Koivula, 1987). Similar material from Japan has lamellar structures about $100 \mathrm{~nm}$ thick (Hirai and Nakazawa, 1982), which give rise to some very rare crystals with patches of color. Diffraction effects probably account for the color phenomena observed in some varieties of agate (e.g., iris agate, fire agate).

Diffraction cannot be induced by any known commercial treatment. However, an already existing diffraction color can be enhanced by inducing a dark background (sugar and smoke treatment of opals, for example, as well as doublets), or by reducing the scattering of light in the matrix through impregnation with various kinds of polymers.
Scattering. When the internal structure of the stone is irregular and/or the size of the components is outside the very narrow range needed for diffraction (approximately $100-400 \mathrm{~nm}$ ), visible light cannot be diffracted. It can, however, still be scattered, the process by which light entering a stone in a given direction is deflected in different directions through interaction with the scattering centers. This creates both striking color effects and optical phenomena. The exact phenomenon depends on the size and shape of the scattering centers. When the scattering centers are smaller than the wavelength of visible light (including down to molecular dimensions) and not regularly distributed, the process is called Rayleigh scattering; when the scattering centers are comparable in size to visible wavelengths, the process is called Mie scattering. (The names are derived from the mathematical theories used to describe scattering.) A third type of scattering occurs when the centers are larger than visible wavelengths.

Rayleigh Scattëring. When the incoming light ray encounters randomly distributed objects smaller

Figure 8. The homogeneous color in a patch of opal arises because light rays entering the stone are diffracted by an orderly array of silica spheres and the holes in between them. The diffracted color depends on the size of the spheres (after Lehmann, 1978).

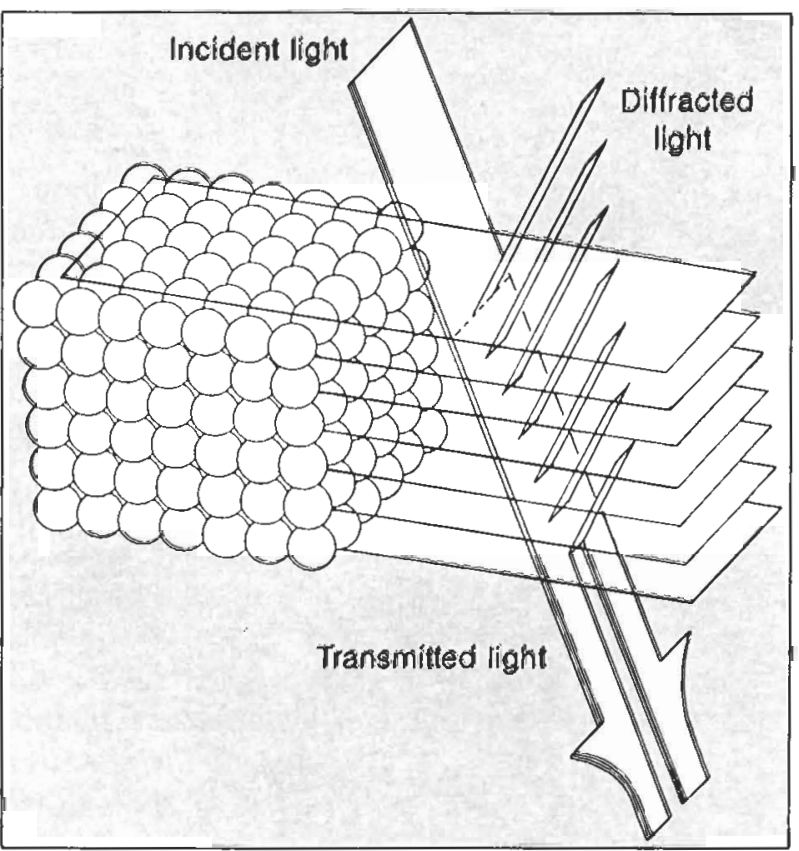


than the wavelengths of visible light, the most energetic radiations-violet and blue-are scattered much more strongly than the others. In fact, violet light is scattered 16 times more efficiently than red. As a result, the majority of the orange-red light passes through the stone and appears as transmitted light, whereas violet and blue light is scattered and can be observed at right angles to the incident beam.

This phenomenon is familiar to all of us as the scattering of sunlight by molecules and molecular aggregates in the upper atmosphere, which causes the sky to appear blue in the daytime (scattered light) and orange-red at dawn and twilight (transmitted light). Examples in gemology are few but well known. Common opal (potch) contains spheres that are too small and too irregularly stacked to diffract. Instead, it has a bluish white appearance called "opalescence," which is due to scattering by the silica spheres. Such an opal indeed also transmits orange light. "Moonstone" is

\section{Figure 9. This extraordinary opal specimen} from Mexica shows a diffraction-caused play-ofcolor zone close to a region of fire opal, which is colored by a combination of diffraction and body absorption by $\mathrm{Fe}^{3+}$ - containing inclusions. Specimen courtesy of the Paris School of Mines; photo (c) Nelly Bariand.

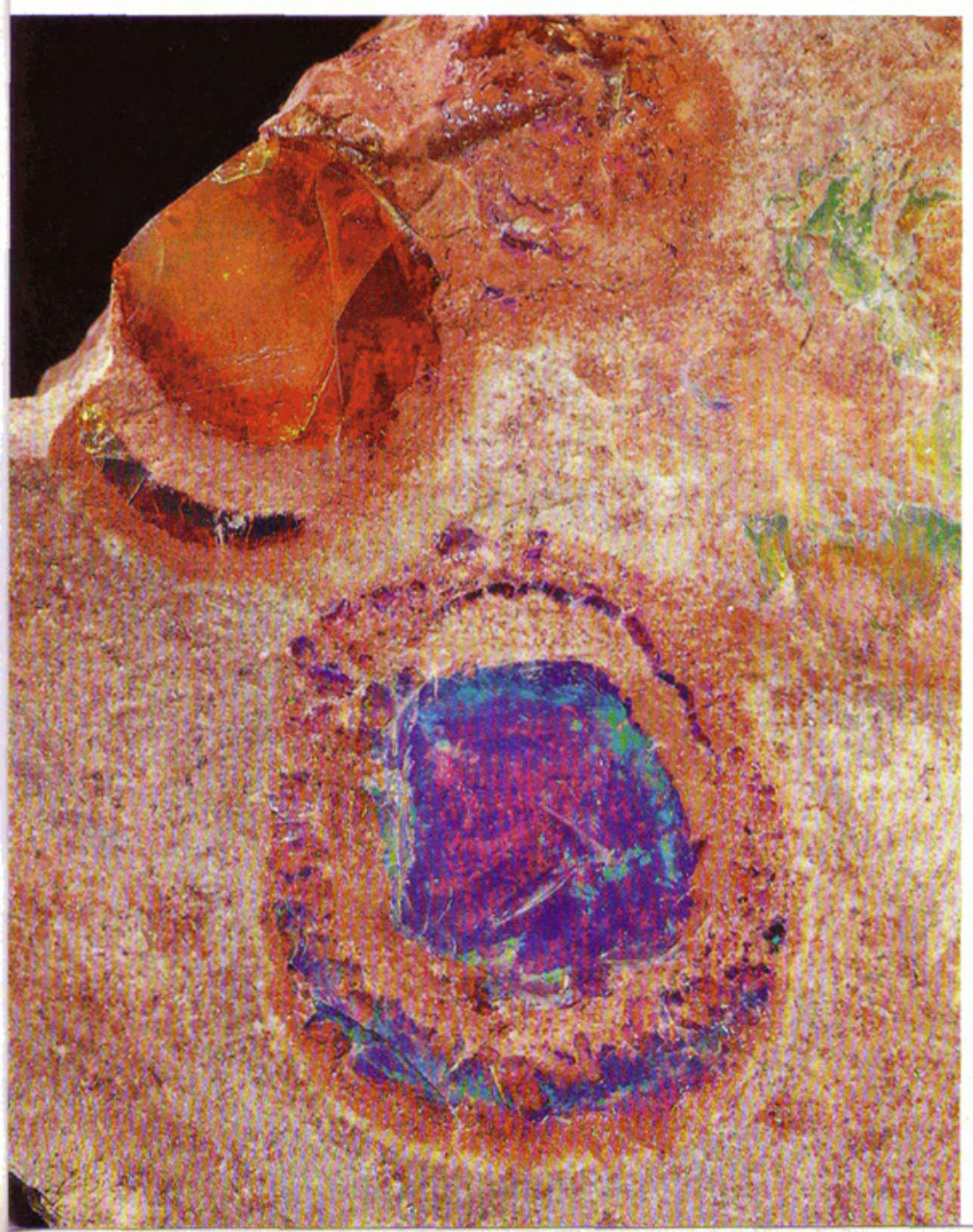

so called because light scattered from exsolution lamellae creates a bluish white "moon-like" hue (in the best specimens; see figure 1). Moonstone is actually an alkali feldspar, with alternating parallel planes of potassium- and sodium-rich feldspars forming an assemblage called a microperthite. These component layers in moonstone range from 50 to $1000 \mathrm{~nm}(1 \mu \mathrm{m})$ thick (Lehmann, 1978). The thinner layers produce the Rayleigh scattering. The same colors from scattering can also occur in plagioclase, and are sometimes called "adularescence." Some blue quartz receives its color from the scattering effect created by dispersed ilmenite inclusions that are approximately $60 \mathrm{~nm}$ in diameter (Zolensky et al., 1988).

Mie Scattering. When the scattering elements are roughly the size of the visible wavelengths, the scattering is best described by the "Mie theory." This theory has applications in gem materials only in those very special cases in which the color is created by metallic inclusions.

A common example is provided by some varieties of violet fluorite. This color is generated by irradiation, which expels a fluorine atom from the crystal, leaving partially bonded calcium atoms behind. Over time, the calcium atoms coagulate and form small hexagonal platelets about the size of visible wavelengths (Lehmann, 1978). Part of the light is absorbed by the calcium crystals and part is reflected. The combined effect of this absorption and reflection is a strong absorption from the green to the red, which leaves a violet transmission window. The position of the bands, and therefore the hue, varies slightly with the size of the metallic particles. Such an effect has been known for a long time in man-made glasses (which are often used as gemstone simulants). "Ruby" glasses are colored by microscopic particles of copper (or gold), and the brown glass used for beer bottles (and to imitate topaz) is usually tinted by metallic oxysulphide precipitates (J. F. Cottrant, pers. comm., 1987).

Scattering from Structural Components Larger than Visible Wavelengths. When the inclusions are larger than the wavelengths of visible light, they scatter light in all directions, including toward the observer's eye. Unlike the case of Rayleigh scattering, all wavelengths are scattered equally and recombine to produce a white light with a translucent milky appearance. This is typical of crystals 

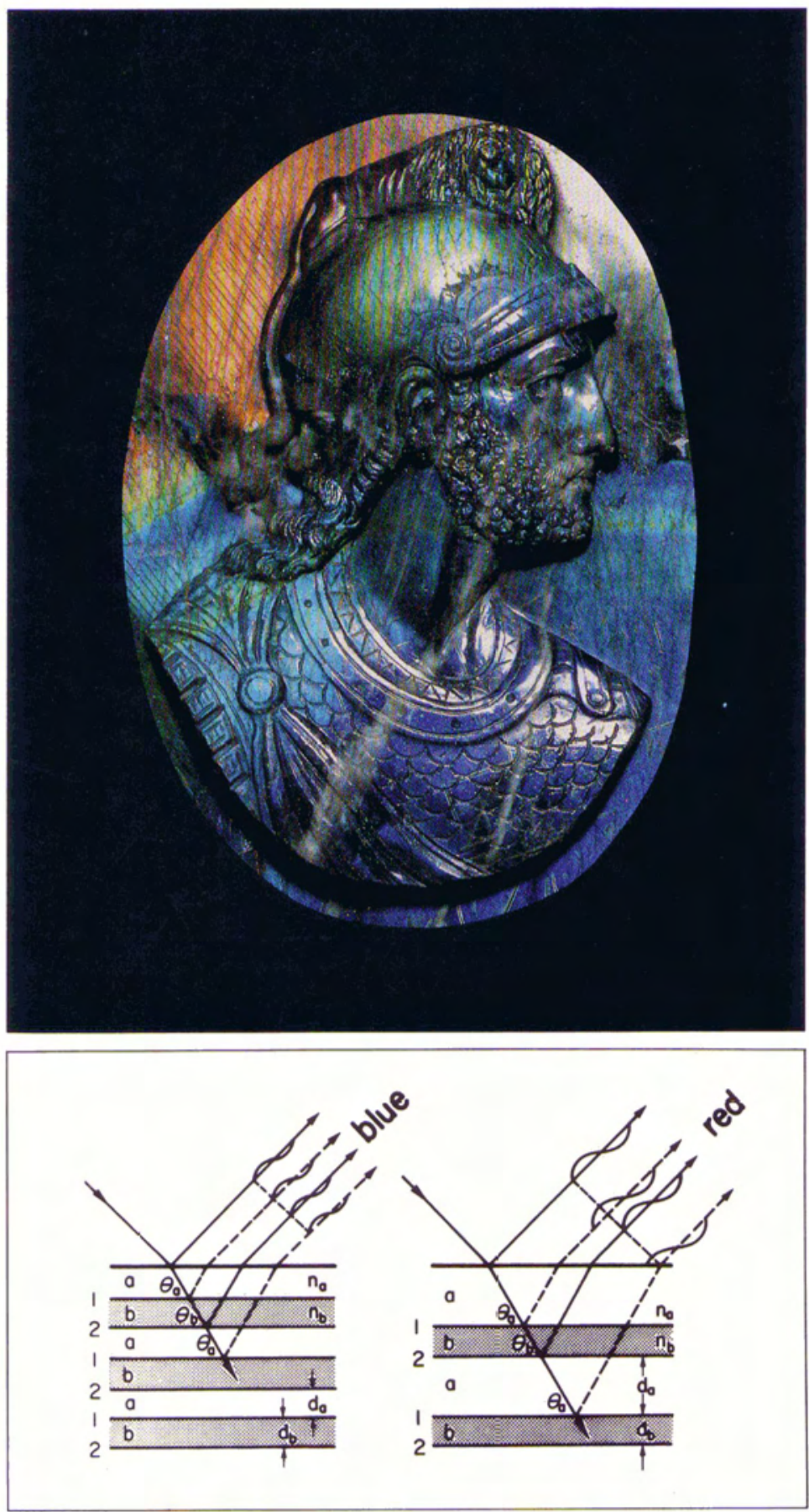

Figure 10. The schematic drawings illustrate why various diffraction colors occur in plagioclase feldspars. The two sets of lamellar feldspars have different thicknesses $\left(d_{a}\right.$ and $\left.d_{b}\right)$ and indices of refraction $\left(n_{a}\right.$ and $\left.n_{b}\right)$; therefore, the light beam will go through interfaces 1 and 2 at different angles $\theta_{a}$ and $\theta_{b}$ ). As a consequence, the beam at interface 2 is retarded relative to the one at interface 1, although the wavelengths are the same, and generally attenuate each other. For one given combination of thicknesses, refractive index, and incident wavelength, the beam from interface 2 is exactly one wavelength behind the beam of interface 1, so they combine in a coherent monochromatic beam. The color of this beam of light is blue for relatively thin lamellae, red for larger ones. The cameo (by Tiffany \&) Co.) is a rare example of carved red and blue labradorite. The line drawing is courtesy of the Mineralogical Record; the photo is by Chip Clark, reprinted by permission of Harry N. Abrams, Inc., courtesy of the Smithsonian Institution. containing pervasive fluid inclusions (such as milky quartz), colorless microcrystals, microfractures, bubbles, and the like.

In some cases, a particular orientation of the scattering elements may produce special optical effects. If they are fibrous, the result is a "white adularescence" or silky sheen, as in gypsum ("satin spar" varietyl, some malachite, or pectolite. Chatoyancy or asterism arises when the scattering elements are sets of parallel fibers, tubes, or plate- lets. These effects, beyond the scope of this article, do not affect color. However, for the sake of clarity and completeness, the various kinds of phenomena (in the gemological sense) have been grouped in table 3 . With the exception of the alexandrite effect, which was discussed in part 1 of this series (Fritsch and Rossman, 1987), all gemstone phenomena can be understood as the interaction of visible light with particles in a particular size range. The size of the particle can be used as a basis 
TABLE 3. Descriptions, causes, and examples of phenomena in gem materials and considerations they require in fashioning. ${ }^{a}$

\begin{tabular}{|c|c|c|c|c|}
\hline Phenomenon & Description & Cause & Examples & $\begin{array}{l}\text { Considerations } \\
\text { in fashioning }\end{array}$ \\
\hline $\begin{array}{l}\text { Iridescence } \\
\text { Orient }\end{array}$ & $\begin{array}{l}\text { Interference colors on, or in, a } \\
\text { stone, like those produced by a } \\
\text { drop of oil on water }\end{array}$ & $\begin{array}{l}\text { Interference of visible light ray's, due to } \\
\text { the presence of a thin film or thin } \\
\text { structure in, or on, a material of } \\
\text { different refractive index }\end{array}$ & $\begin{array}{l}\text { Iris quartz, } \\
\text { "ammolite," } \\
\text { pearls }\end{array}$ & $\begin{array}{l}\text { Thin film or } \\
\text { structure } \\
\text { oriented to the } \\
\text { girdle plane }\end{array}$ \\
\hline $\begin{array}{l}\text { Play-of-color } \\
\text { Labrador- } \\
\text { escence }\end{array}$ & $\begin{array}{l}\text { On a given spot, for a given } \\
\text { illumination angle, only one } \\
\text { pure spectral color is seen, } \\
\text { rotating the stone changes the } \\
\text { color }\end{array}$ & $\begin{array}{l}\text { Diffraction of visible light by regularly } \\
\text { layered structures smaller than the } \\
\text { visible wavelengths }\end{array}$ & $\begin{array}{l}\text { Opal, feldspar } \\
\text { ("spectrolite") }\end{array}$ & $\begin{array}{l}\text { Diffraction } \\
\text { layers oriented } \\
\text { parallel to the } \\
\text { girdle plane }\end{array}$ \\
\hline Adularescence & Floating bluish sheen in a stone & $\begin{array}{l}\text { Scattering of visible light by randomly } \\
\text { distributed structures smaller than } \\
\text { visible wavelengths }\end{array}$ & $\begin{array}{l}\text { Feldspar } \\
\text { (moonstone) }\end{array}$ & No relation \\
\hline $\begin{array}{l}\text { Chatoyancy } \\
\text { ("cat's-eye") } \\
\text { Asterism }\end{array}$ & $\begin{array}{l}\text { One or more lines of white light } \\
\text { appearing on a curved surface } \\
\text { (chatoyancy }=\text { one ray, like a } \\
\text { cat's eye; asterism = several } \\
\text { rays-up to } 6 \text {-- building a star) }\end{array}$ & $\begin{array}{l}\text { Scattering of light by oriented parallel } \\
\text { needle-like or plate-like inclusions or } \\
\text { structures larger than visible } \\
\text { wavelengths (chatoyancy = one set of } \\
\text { inclusions or structures; asterism = } \\
\text { multiple sets) }\end{array}$ & $\begin{array}{l}\text { Chrysoberyl, } \\
\text { corundum, } \\
\text { quartz, } \\
\text { diopside }\end{array}$ & $\begin{array}{l}\text { Curved surface } \\
\text { (not well } \\
\text { focused on flat } \\
\text { surface) }\end{array}$ \\
\hline Aventurescence & $\begin{array}{l}\text { Colored metallic-like spangles } \\
\text { in the stone, especially obvious } \\
\text { when the stone is rotated in } \\
\text { reflected light }\end{array}$ & $\begin{array}{l}\text { Reflection of light by large eye-visible } \\
\text { plate-like inclusions }\end{array}$ & $\begin{array}{l}\text { Aventurine } \\
\text { quartz, feldspar } \\
\text { (sunstone), } \\
\text { goldstone glass }\end{array}$ & No relation \\
\hline $\begin{array}{l}\text { Change-of- } \\
\text { color } \\
\text { ("Alexandrite } \\
\text { effect") }\end{array}$ & $\begin{array}{l}\text { The stone changes color when } \\
\text { the illumination is switched from } \\
\text { sunlight or fluorescent light to } \\
\text { incandescent light }\end{array}$ & $\begin{array}{l}\text { A major absorption band around } 550- \\
600 \mathrm{~nm} \text { cuts the visible range in two } \\
\text { transmission windows: one at the blue } \\
\text { end (dominating in daylight), the other } \\
\text { at the red end (dominating in } \\
\text { incandescent light) }\end{array}$ & $\begin{array}{l}\text { Chrysoberyl } \\
\text { (alexandrite), } \\
\text { corundum, } \\
\text { garnet, spinel, } \\
\text { fluorite }\end{array}$ & $\begin{array}{l}\text { Observed in } \\
\text { all directions, } \\
\text { better colors } \\
\text { in some }\end{array}$ \\
\hline
\end{tabular}

aThis table includes all terms used tor phenomena in gem materials. It describes each of the phenomena and shows how similar some of them are and how others relate to one another almost in a continuum.

for classification. There is a continuum in the size of the particles between color-creating phenomena (such as adularescence) and phenomena that do not affect color (such as chatoyancy). This continuum is emphasized in table 3.

Some of these phenomena can be induced or enhanced by treatment-especially heat treatment. Basically, the heat precipitates a second phase in the matrix, which creates oriented inclusions, which in turn induce chatoyancy or asterism (Nassau, 1984).

Presence of Colored Inclusions. The last type of coloration encountered in gemstones is coloration caused by the body color of inclusions in a nearcolorless host crystal. These inclusions can be extremely small, like the nickeliferous clays that color chrysoprase or the small hydrous iron oxide crystals that make carnelian orange (figure 11). Somewhat larger but still microscopic inclusions of hematite cause the color of red orthoclase from
Madagascar (Malagasy Republic) and some cordierites ("bloodshot iolite"). Fire opal is colored by submicroscopic inclusions of iron hydrous oxides (J. Koivula, pers. comm., 19881.

When the platelets are large enough to be distinguished with the naked eye (say, when they reach $1 \mathrm{~mm}$ ), they can produce "aventurescence." This term is used to describe the reflective powderlike appearance of crystalline flakes disposed $a$ l'aventurra (the term refers to a Murano glassfirst made in Venice, Italy - in which copper platelets have been dispersed at random). In aventurine quartz, mica crystals colored green by chromium sparkle when the stone is tilted back and forth. "Sunstone" can be either native-copper-included labradorite (most commonly), or oligoclase containing red hematite spangles (again, see figure 1).

\section{SUMMARY AND CONCLUSION}

In most gem materials, color is caused by selective absorption of light by different processes. In a few 
TABLE 4. Causes of color in most gem materials. ${ }^{a}$

\begin{tabular}{|c|c|c|c|}
\hline Gem material & $\begin{array}{l}\text { Color (variety or } \\
\text { trade name, if any) }\end{array}$ & Cause & Reference \\
\hline \multirow[t]{2}{*}{ Actinolite } & $\begin{array}{l}\text { Yellowish green to } \\
\text { green (nephrite) }\end{array}$ & $\begin{array}{l}\mathrm{Fe}^{2+} \text { in octahedral } \\
\text { coordination }\end{array}$ & Burns, 1970 \\
\hline & Green & Traces of $\mathrm{Cr}^{3+}$ & Anderson, 1954-55 \\
\hline Almandine & Red & $\begin{array}{l}\mathrm{Fe}^{2}+\text { in distorted } \\
\text { cubic coordination }\end{array}$ & Manning. 1967a \\
\hline \multirow[t]{2}{*}{ Amber } & Blue to green & $\begin{array}{l}\text { Fluorescence under } \\
\text { visible light in } \\
\text { Dominican amber; } \\
\text { blue is due to light } \\
\text { (Rayleigh) scatter- } \\
\text { ing in Baltic amber }\end{array}$ & Schlee, 1984 \\
\hline & $\begin{array}{l}\text { Yellow to orange to } \\
\text { red to brown }\end{array}$ & $\begin{array}{l}\text { Charge-transter } \\
\text { processes in large } \\
\text { organic molecules }\end{array}$ & Nassau, 1975a \\
\hline
\end{tabular}

Amphibole group (see actinolite, anthophyllite and gedrite, glaucophane, hornblende and pargasite, or tremolite)

\begin{tabular}{|c|c|c|c|}
\hline \multirow[t]{2}{*}{ Andalusite } & $\begin{array}{l}\text { Green and brown, } \\
\text { pleochroism }\end{array}$ & $\begin{array}{l}\mathrm{Fe}^{2+-O}-\mathrm{Ti}^{4+} \\
\text { charge transfer }\end{array}$ & Smith, 1977 \\
\hline & $\begin{array}{l}\text { Dark green } \\
\text { (víridine) }\end{array}$ & $\begin{array}{l}M n^{3+} \text { in octahedral } \\
\text { coordination }\end{array}$ & Smith et al., 1982 \\
\hline \multirow[t]{2}{*}{ Andradite } & Multicolors & Diffraction & $\begin{array}{l}\text { Hirai and } \\
\text { Nakazawa, 1982; } \\
\text { Koivula, } 1987\end{array}$ \\
\hline & Yellow-green & $\begin{array}{l}\mathrm{Fe}^{3}+\text { in octahedral } \\
\text { coordination }\end{array}$ & $\begin{array}{l}\text { Manning, 1967b, } \\
1972\end{array}$ \\
\hline
\end{tabular}

This 1759-ct emerald from the collection of the Banco de la República in Bogotá, Colombia, owes its magnificent color to a small amount of $\mathrm{Cr}^{3+}$ in octahedral coordination. Photo (c) Harold e) Erica Van Pelt.

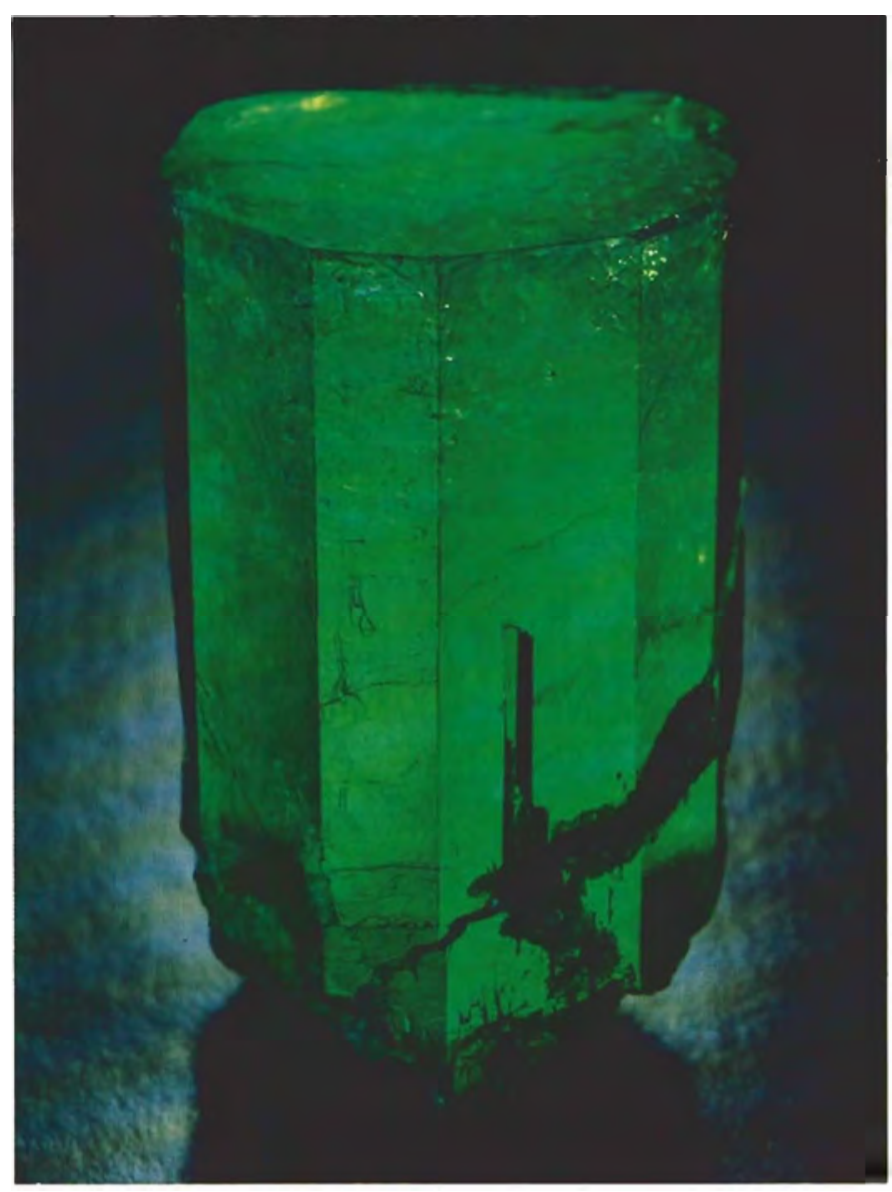

\begin{tabular}{|c|c|c|c|}
\hline Gem materlal & $\begin{array}{l}\text { Color (variety or } \\
\text { trade name, if any) }\end{array}$ & Cause & Reference \\
\hline & Green (demantoid) & $\begin{array}{l}\mathrm{Cr}^{3}+\text { in octahedral } \\
\text { coordination }\end{array}$ & $\begin{array}{l}\text { Anderson, } 1954- \\
55 ; \text { Stockton and } \\
\text { Mianson, } 1983 \text {, } \\
1984\end{array}$ \\
\hline & $\begin{array}{l}\text { Yellow (topazolite) } \\
\text { to black (melanite) }\end{array}$ & $\begin{array}{l}\text { Various charge- } \\
\text { transfer processes } \\
\text { and dispersed ion } \\
\text { absorption involv- } \\
\text { ing Fe and } \mathrm{Ti}\end{array}$ & $\begin{array}{l}\text { Dowty, 1971; Moore } \\
\text { and White, } 1971\end{array}$ \\
\hline $\begin{array}{l}\text { Anthophyllite and } \\
\text { gedrite (ortho- } \\
\text { amphiboles) }\end{array}$ & $\begin{array}{l}\text { Multicolor } \\
\text { ("nuummite") }\end{array}$ & $\begin{array}{l}\text { "Iridescence," likely } \\
\text { diffraction }\end{array}$ & $\begin{array}{l}\text { Appel and Jensen, } \\
1987\end{array}$ \\
\hline \multirow[t]{2}{*}{ Apatite series } & Pink & $\begin{array}{l}\text { F vacancy with a } \\
\text { trapped electron }\end{array}$ & Marfunin, $1979 b$ \\
\hline & Dark blue & $\begin{array}{l}\mathrm{O}^{2-} \rightarrow \mathrm{Mn}^{5}+\text { charge } \\
\text { transfer }\end{array}$ & Marlunin, 1979b \\
\hline Apophyllite & Green & $\begin{array}{l}V_{A+} \text { in distorted oc- } \\
\text { tahedral coordina- } \\
\text { tion }\end{array}$ & Rossman, 1974a \\
\hline \multirow[t]{2}{*}{$\begin{array}{l}\text { Axinite } \\
\text { group }\end{array}$} & Blue & $\begin{array}{l}\text { V3 + in octahedral } \\
\text { coordination }\end{array}$ & Schmelzer, 1982 \\
\hline & Brown & $\mathrm{Fe}^{2+}$ & Faye, 1972 \\
\hline Azurite & Blue & $\begin{array}{l}\mathrm{Cu}^{2+} \text { in elongated } \\
\text { oclahedral coor- } \\
\text { dination }\end{array}$ & Marfunın, 1979a \\
\hline Benitoite & Blue & $\begin{array}{l}\mathrm{Fe}^{2+}+\mathrm{O}-\mathrm{Ti} 4+ \\
\text { charge transfer }\end{array}$ & $\begin{array}{l}\text { Not fully proven: } \\
\text { Burns, } 1970\end{array}$ \\
\hline \multirow[t]{8}{*}{ Beryl } & $\begin{array}{l}\text { Dark blue (Maxixe } \\
\text { and Maxixe-type) }\end{array}$ & $\begin{array}{l}\mathrm{CO}_{3}^{-} \text {(Maxixe-type) } \\
\text { and } \mathrm{NO}_{3} \text { (Maxixe) } \\
\text { color centers due } \\
\text { to irradiation }\end{array}$ & Andersson, 1979 \\
\hline & $\begin{array}{l}\text { Light blue (aqua- } \\
\text { marine) }\end{array}$ & $\begin{array}{l}\mathrm{Fe}^{2+} \text { in the chan- } \\
\text { nels of the structure }\end{array}$ & $\begin{array}{l}\text { Goldman et al. } \\
1978\end{array}$ \\
\hline & $\begin{array}{l}\text { Darker blue (aqua- } \\
\text { marine) }\end{array}$ & $\begin{array}{l}\mathrm{Fe}^{2+}-\mathrm{O}-\mathrm{Fe}^{3+} \text { inter- } \\
\text { valence charge } \\
\text { transfer }\end{array}$ & $\begin{array}{l}\text { Goldman et al., } \\
1978\end{array}$ \\
\hline & $\begin{array}{l}\text { Green: yellow + } \\
\text { blue }\end{array}$ & $\begin{array}{l}\mathrm{O}^{2-} \rightarrow \mathrm{Fe}^{3+} \text { charge } \\
\text { transfer and } \mathrm{Fe}^{2+} \\
\text { in the channels }\end{array}$ & $\begin{array}{l}\text { G. Rossman, un- } \\
\text { pub. data }\end{array}$ \\
\hline & $\begin{array}{l}\text { Green (emerald) } \\
\text { and light green } \\
\text { ("mint beryl") }\end{array}$ & $\begin{array}{l}\mathrm{Cr}^{3+} \text { and/or } \mathrm{V}^{3}+\text { in } \\
\text { octahedral coor- } \\
\text { dination }\end{array}$ & $\begin{array}{l}\text { Wood and Nassau, } \\
1968\end{array}$ \\
\hline & $\begin{array}{l}\text { Yellow to orange } \\
\text { (heliodor) }\end{array}$ & $\begin{array}{l}\mathrm{O}^{2-} \rightarrow \mathrm{Fe}^{3+} \text { charge } \\
\text { transier }\end{array}$ & $\begin{array}{l}\text { Loeffler and Burns, } \\
\text { 1976: Goldman et } \\
\text { al., } 1978\end{array}$ \\
\hline & Red & $\begin{array}{l}\mathrm{Mn}^{3+} \text { in octahedral } \\
\text { coordination }\end{array}$ & $\begin{array}{l}\text { Shigley and Foord, } \\
1984\end{array}$ \\
\hline & Pink (morganite) & $\begin{array}{l}\mathrm{Mn}^{2+} \text { in octahedral } \\
\text { coordination }\end{array}$ & $\begin{array}{l}\text { Wood and Nassau, } \\
1968\end{array}$ \\
\hline Calcite & Pink & $\mathrm{CO}^{2+}$ & $\begin{array}{l}\text { Webster, 1983; } \\
\text { Rossman, } 1988\end{array}$ \\
\hline \multirow[t]{4}{*}{ Chalcedony } & Purple & $\begin{array}{l}\text { Microscopic sugilite } \\
\text { inclusions }\end{array}$ & Shigley et al., 1987 \\
\hline & $\begin{array}{l}\text { Purple } \\
\text { ("damsonite") }\end{array}$ & $\begin{array}{l}\text { Color center similar } \\
\text { to that found in am- } \\
\text { ethyst }\end{array}$ & $\begin{array}{l}\text { Shigley and } \\
\text { Koivula, } 1985\end{array}$ \\
\hline & $\begin{array}{l}\text { Blue to greenish } \\
\text { blue (chrysocolla } \\
\text { quartz) }\end{array}$ & $\begin{array}{l}\text { Microscopic to sub- } \\
\text { microscopic inclu- } \\
\text { sions of chrysocolla }\end{array}$ & $\begin{array}{l}\text { J. Koivula, pers. } \\
\text { comm., } 1988\end{array}$ \\
\hline & $\begin{array}{l}\text { Green } \\
\text { (chrysoprase) }\end{array}$ & $\begin{array}{l}\text { Microscopic inclu- } \\
\text { sions of nickel- } \\
\text { iferous clay-like ma- } \\
\text { terial }\end{array}$ & $\begin{array}{l}\text { A. Nianceau, pers. } \\
\text { comm., } 1985\end{array}$ \\
\hline
\end{tabular}

aThis list of the origin of color in gem materials is based on spectra or explicit discussions as they appear in the literalure or have been communicated to the authors. One color can be due to a combination of processes, while visually similar colors can have a variety of different causes. Whithin each gem group or subgroup, colors are listed in the order of the spectrum. from violet through purple, blue, green, yellow, and orange to red, and then pink, brown, black, and white when relevant. Dyes and colored coatings can be used on many of these materials, but they are mentioned here only if they are the most common cause of color in a particular malerial. 


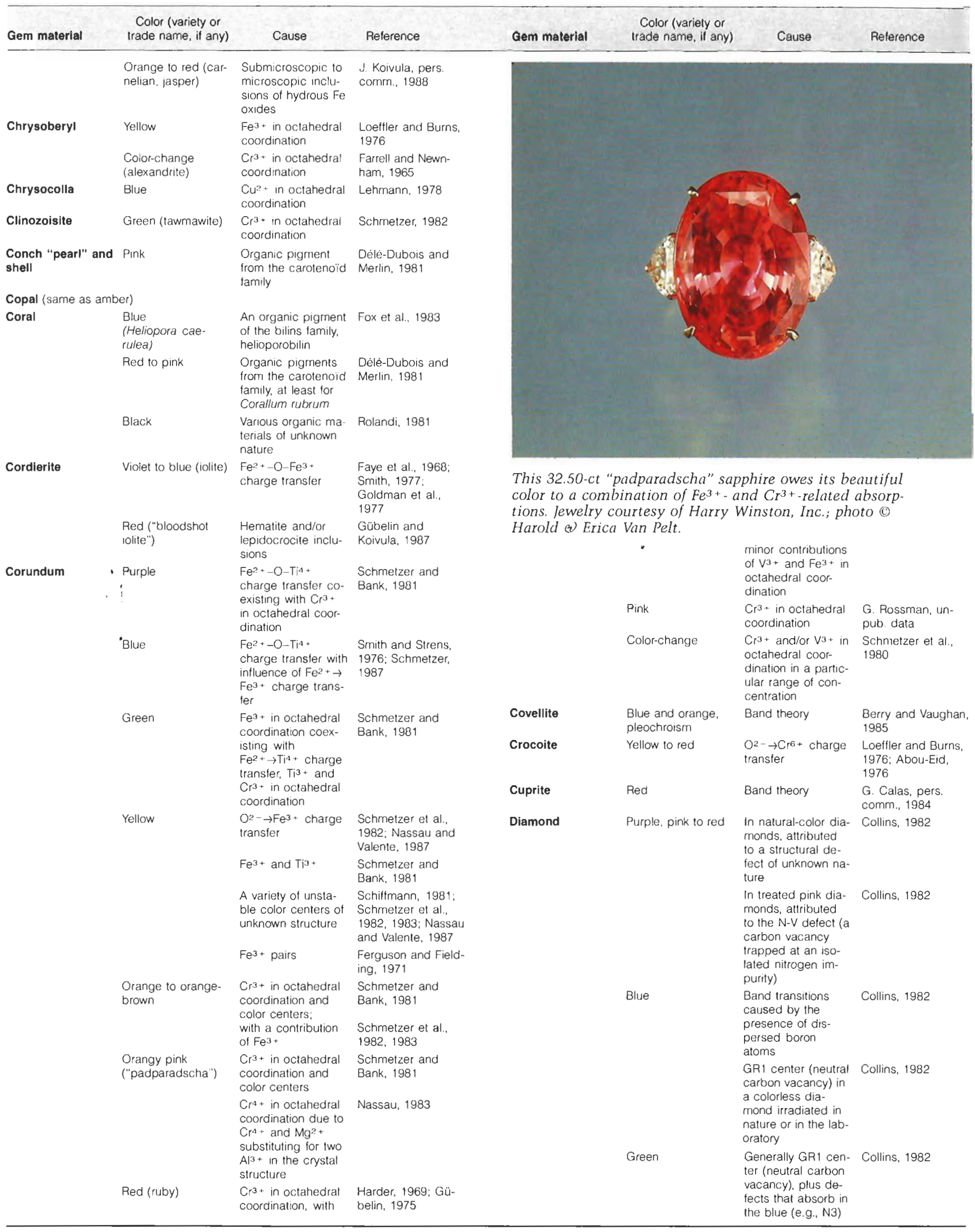




\begin{tabular}{|c|c|c|c|c|c|c|c|}
\hline Gem material & $\begin{array}{l}\text { Color (variety or } \\
\text { trade name, if any) }\end{array}$ & Cause & Reterence & Gem material & $\begin{array}{l}\text { Color (variety or } \\
\text { trade name, if any) }\end{array}$ & Cause & Reference \\
\hline & \multirow{10}{*}{ Yellow } & \multirow{3}{*}{$\begin{array}{l}\text { More rarely, due to } \\
\text { very strong green } \\
\text { fluorescence under } \\
\text { visible ligh! ("green } \\
\text { transmitter" elfect) } \\
\text { of the } \mathrm{H} 3 \text { and/or } \mathrm{H} 4 \\
\text { defect (a carbon } \\
\text { vacancy trapped at } \\
\text { an aggregate of } \\
\text { two or tour nitrogen } \\
\text { atoms) }\end{array}$} & \multirow[t]{3}{*}{ Collins, 1982} & & Greenish yellow & $\begin{array}{l}\mathrm{Mn}^{2}+\text { in oclahedral } \\
\text { coordination (rare) }\end{array}$ & $\begin{array}{l}\text { Rossman and } \\
\text { Mattson, } 1986\end{array}$ \\
\hline & & & & & Orange & Yellow + pink & See Dietrich, 1985 \\
\hline & & & & & $\begin{array}{l}\text { Pink to red } \\
\text { (rubellite) }\end{array}$ & $\begin{array}{l}\text { Related to man- } \\
\text { ganese, generally } \\
\text { believed to be due } \\
\text { to } \mathrm{Mn}^{3}+\text { in octa- } \\
\text { hedral coordination. } \\
\text { sometimes created } \\
\text { by irradiation }\end{array}$ & $\begin{array}{l}\text { Manning, } 1973 ; \text { De } \\
\text { Camargo and Iso- } \\
\text { tani. } 1988\end{array}$ \\
\hline & & \multirow{4}{*}{$\begin{array}{l}\text { Most commonly } \\
\text { due to the N3 de- } \\
\text { fect, an aggregate } \\
\text { of three nitrogen } \\
\text { atoms (color cen- } \\
\text { ler) at a carbon va- } \\
\text { cancy }\end{array}$} & \multirow{4}{*}{$\begin{array}{l}\text { Collins, } 1982 \\
\text { Lowther, } 1984\end{array}$} & \multirow{3}{*}{ Enstatite } & Brown & $\begin{array}{l}\mathrm{Fe}^{2}+\rightarrow \mathrm{T}^{4}+\text { charge } \\
\text { transter }\end{array}$ & $\begin{array}{l}\text { Rossman and } \\
\text { Mattson, } 1986\end{array}$ \\
\hline & & & & & Greenish brown & $\mathrm{Fe}^{2+}$ & Rossman, 1980 \\
\hline & & & & & Green & $\begin{array}{l}\mathrm{Fe}^{2}+\text { with rninor } \\
\mathrm{C} r^{3}+\end{array}$ & Anderson, 1954-55 \\
\hline & & & & \multicolumn{3}{|c|}{ Epidote group (see clinozoisite, epidote, piemontite, or zoisite) } & \\
\hline & & \multirow{3}{*}{$\begin{array}{l}\text { More rarely, due to } \\
\text { band transitions } \\
\text { caused by the } \\
\text { presence of iso- } \\
\text { lated nitrogen } \\
\text { atoms }\end{array}$} & \multirow[t]{3}{*}{ Collins, 1982} & Epidote & $\begin{array}{l}\text { Green and brown, } \\
\text { pleochroism }\end{array}$ & $\begin{array}{l}\mathrm{Fe}^{3+} \text { in distorted } \\
\text { octahedral coor- } \\
\text { dination }\end{array}$ & Burns, 1970 \\
\hline & & & & Euclase & Blue & $\begin{array}{l}\mathrm{Fe}^{2+}-\mathrm{O}-\mathrm{Fe}^{3+} \\
\text { charge transter }\end{array}$ & $\begin{array}{l}\text { Maltson and Ross- } \\
\text { man, } 1987\end{array}$ \\
\hline & & & & & Green & $\mathrm{Cr} 3+$ in octahedral & Anderson, 1954-55 \\
\hline & \multirow[t]{5}{*}{ Orange } & \multirow{4}{*}{$\begin{array}{l}\text { Most commonly } \mathrm{H} 3 \\
\text { center (a carbon } \\
\text { vacancy trapped at } \\
\text { an aggregate of } \\
\text { iwo nilrogen } \\
\text { atoms), in natural } \\
\text { and treated orange } \\
\text { diamonds }\end{array}$} & \multirow{4}{*}{$\begin{array}{l}\text { Cottrant and Calas, } \\
1981\end{array}$} & \multirow{2}{*}{\multicolumn{4}{|c|}{$\begin{array}{l}\text { Feldspar group (see labradorite. microcline, oligoclase, orthoclase, or plagioclase } \\
\text { series) }\end{array}$}} \\
\hline & & & & & & & \\
\hline & & & & \multirow[t]{9}{*}{ Fluorite } & Violet & $\begin{array}{l}\text { Mie scattering on } \\
\text { calcium micro- } \\
\text { crystallites }\end{array}$ & $\begin{array}{l}\text { Braithwaite el al., } \\
\text { 1973; Lehmann, } \\
1978\end{array}$ \\
\hline & & & & & Blue & $\mathrm{Y}^{3}++\mathrm{F}$ vacancy & Bill and Calas, \\
\hline & & $\begin{array}{l}\text { More rarely, origi- } \\
\text { nating from a color } \\
\text { center of unknown } \\
\text { nature }\end{array}$ & Collins, 1982 & & $\begin{array}{l}\text { "Emerald" green } \\
\text { ("chrome fluorite") }\end{array}$ & $\begin{array}{l}+2 \text { electrons } \\
\mathrm{Sm}^{2}+\end{array}$ & $\begin{array}{l}1978 \\
\text { Bill and Calas, } \\
1978 ; \text { Fossman. } \\
1981\end{array}$ \\
\hline & Brown & $\begin{array}{l}\text { Color center of un- } \\
\text { known nature, with } \\
\text { various other color } \\
\text { centers adding or- }\end{array}$ & Collins, 1982 & & Yellowish green & $\begin{array}{l}\text { Color center con- } \\
\text { taining } Y \text { and } \mathrm{Ce} \\
\text { associated with an } \\
F \text { vacancy }\end{array}$ & $\begin{array}{l}\text { Bill and Calas, } \\
1978\end{array}$ \\
\hline & & $\begin{array}{l}\text { ange, yellow, pink, } \\
\text { or green }\end{array}$ & & & Yellow & $\begin{array}{l}\mathrm{O}_{3}^{-} \text {color center = } \\
\mathrm{O}_{2} \text { substituting for } \\
\text { fluorite }\end{array}$ & $\begin{array}{l}\text { Bill and Calas. } \\
1978\end{array}$ \\
\hline \multirow[t]{3}{*}{ Diopside } & \multirow[t]{2}{*}{$\begin{array}{l}\text { Green (chrome } \\
\text { diopside) }\end{array}$} & \multirow{2}{*}{$\begin{array}{l}\mathrm{Cr}^{3}+\text { in octahedral } \\
\text { coordination; } \\
\mathrm{V}^{3}+\text { in octahedral } \\
\text { coordination }\end{array}$} & Rossman, 1980 & & Pink & $\begin{array}{l}\mathrm{YO}_{2} \text { color center } \\
\left(\mathrm{Y}_{3}++\mathrm{O}_{2}^{3-}\right)\end{array}$ & $\begin{array}{l}\text { Bill and Calas. } \\
1978\end{array}$ \\
\hline & & & Schmetzer, 1982 & & \multirow[t]{3}{*}{ Color change } & \multirow{3}{*}{$\begin{array}{l}\mathrm{Y}^{3+} \text {-associated } \\
\text { color center and } \\
\mathrm{Sm}^{2+} \text {, with minor } \\
\text { influence of a } \\
\mathrm{Ce}^{3+} \text {-associated } \\
\text { color center }\end{array}$} & \multirow{3}{*}{$\begin{array}{l}\text { Bill and Calas, } \\
\text { 1978; Schmetzer et } \\
\text { al., } 1980\end{array}$} \\
\hline & Yellowish green & $\begin{array}{l}\mathrm{Fe}^{2}+\text { in octahedral } \\
\text { coordination }\end{array}$ & Burns, 1970 & & & & \\
\hline Dioptase & Green & $\begin{array}{l}\mathrm{Cu}^{2+}+\text { in octahedral } \\
\text { coordination }\end{array}$ & Lehmann, 1978 & & & & \\
\hline \multirow[t]{6}{*}{ Dravite } & \multirow{2}{*}{$\begin{array}{l}\text { Green } \\
\text { ("chrome } \\
\text { tourmaline") }\end{array}$} & \multirow{2}{*}{$\begin{array}{l}\mathrm{V}^{3}+\text { generally with } \\
\text { minor amounts of } \\
\mathrm{Cr}^{3}+\text { both in octa- } \\
\text { hedral coordination }\end{array}$} & $\begin{array}{l}\text { Schmetzer and } \\
\text { Bank. } 1979\end{array}$ & $\begin{array}{l}\text { Gahnite and } \\
\text { "gahnospinel" }\end{array}$ & Blue & $\begin{array}{l}\mathrm{Fe}^{2+} \text { in tetrahedral } \\
\text { coordination }\end{array}$ & $\begin{array}{l}\text { Dickson and Smith, } \\
1976\end{array}$ \\
\hline & & & & \multicolumn{4}{|c|}{$\begin{array}{l}\text { Garnet group (see almandine, andradite, grossular, hydrogrossular group, pyrope, } \\
\text { spessartine, or uvarovite; also rhodolite) }\end{array}$} \\
\hline & \multirow[t]{3}{*}{ Yellow to brown } & $\begin{array}{l}\text { Related to titanium: } \\
\text { due to } \mathrm{Fe}^{2+-O}- \\
\mathrm{Ti}^{4}+\text { charge trans- }\end{array}$ & $\begin{array}{l}\text { Smith, 1977; Ross- } \\
\text { man, as cited in } \\
\text { Dietrich, } 1985\end{array}$ & $\begin{array}{l}\text { Glass } \\
\text { (natural) }\end{array}$ & $\begin{array}{l}\text { Yellowish green } \\
\text { (moldavite, tektite) }\end{array}$ & $\begin{array}{l}\text { Fe? } e^{2+} \text { in octahedral } \\
\text { coordination }\end{array}$ & Pye et al., 1984 \\
\hline & & $\begin{array}{l}\text { ter, with those low } \\
\text { in iron yellow and }\end{array}$ & & & Brown & $\begin{array}{l}\mathrm{Fe}^{\mathrm{J}+} \text { in octahedral } \\
\text { coordination }\end{array}$ & Pye et al., 1984 \\
\hline & & $\begin{array}{l}\text { those rich in iron } \\
\text { brown }\end{array}$ & & Glaucophane & Blue & $\begin{array}{l}\mathrm{Fe}^{2+-}-\mathrm{O}-\mathrm{Fe}^{3+} \\
\text { charge transier }\end{array}$ & $\begin{array}{l}\text { Smith and Strens, } \\
1976\end{array}$ \\
\hline & Red & $\mathrm{Fe}^{3+}$ pairs & $\begin{array}{l}\text { Mattson and Ross- } \\
\text { man, } 1984\end{array}$ & Grossular & Green (tsavorite) & $\begin{array}{l}\mathrm{V}^{3}+\text { in octahedral } \\
\text { coordination }\end{array}$ & $\begin{array}{l}\text { Gübelin and } \\
\text { Weibel, } 1975\end{array}$ \\
\hline $\begin{array}{l}\text { Elbaite } \\
\text { and } \\
\text { liddicoatite }\end{array}$ & $\begin{array}{l}\text { Blue } \\
\text { (indicolite) }\end{array}$ & $\begin{array}{l}\mathrm{Fe}^{2+} \text { in octahedral } \\
\text { coordination with } \\
\text { possible influence } \\
\text { of some iron-related } \\
\text { charge-transter pro- }\end{array}$ & See Dietrich, 1985 & & $\begin{array}{l}\text { Orange } \\
\text { (hessonite) }\end{array}$ & $\begin{array}{l}\mathrm{Mn}^{2+} \text { in distorted } \\
\text { cubic coordination; } \\
\mathrm{Fe}^{3+}\end{array}$ & $\begin{array}{l}\text { Manning. } 1970 \\
\text { Manson and Stock- } \\
\text { tan, } 1986\end{array}$ \\
\hline & & cesses & & Gypsum & All (alabaster) & Color usually due to & J. Koivula, pers. \\
\hline & Green & $\begin{array}{l}\mathrm{Fe}^{2+} \text { and } \mathrm{TiA}^{4} \text { in } \\
\text { octahedral coor- } \\
\text { dination. The influ- } \\
\text { ence of various } \\
\text { charge transfer pro- }\end{array}$ & $\begin{array}{l}\text { Mattson, as cited in } \\
\text { Dietrich, } 1985\end{array}$ & & & $\begin{array}{l}\text { dyes exclusively, } \\
\text { except for some } \\
\text { brown staining due } \\
\text { to hydrous iron } \\
\text { oxides }\end{array}$ & \\
\hline & & $\begin{array}{l}\text { cesses involving } \\
\text { iron is a distinct }\end{array}$ & & Hematite & $\begin{array}{l}\text { Gray in reflection, } \\
\text { red in Iransmission }\end{array}$ & $\mathrm{Fe}^{3+}$ & Bell et al., 1975 \\
\hline & & possibility & & Hornblende & Green to brown & $\mathrm{Fe}^{2}+$ in various & Rossman, 1988 \\
\hline & Yellow-green & $\mathrm{Mn}^{2+}+\mathrm{O}-\mathrm{Ti}^{4+}$ & Rossman and & and pargasite & & sites & \\
\hline & & & & Howlite & Blue & Dyes exclusively & \\
\hline
\end{tabular}

96 Color in Gems, Part 3 


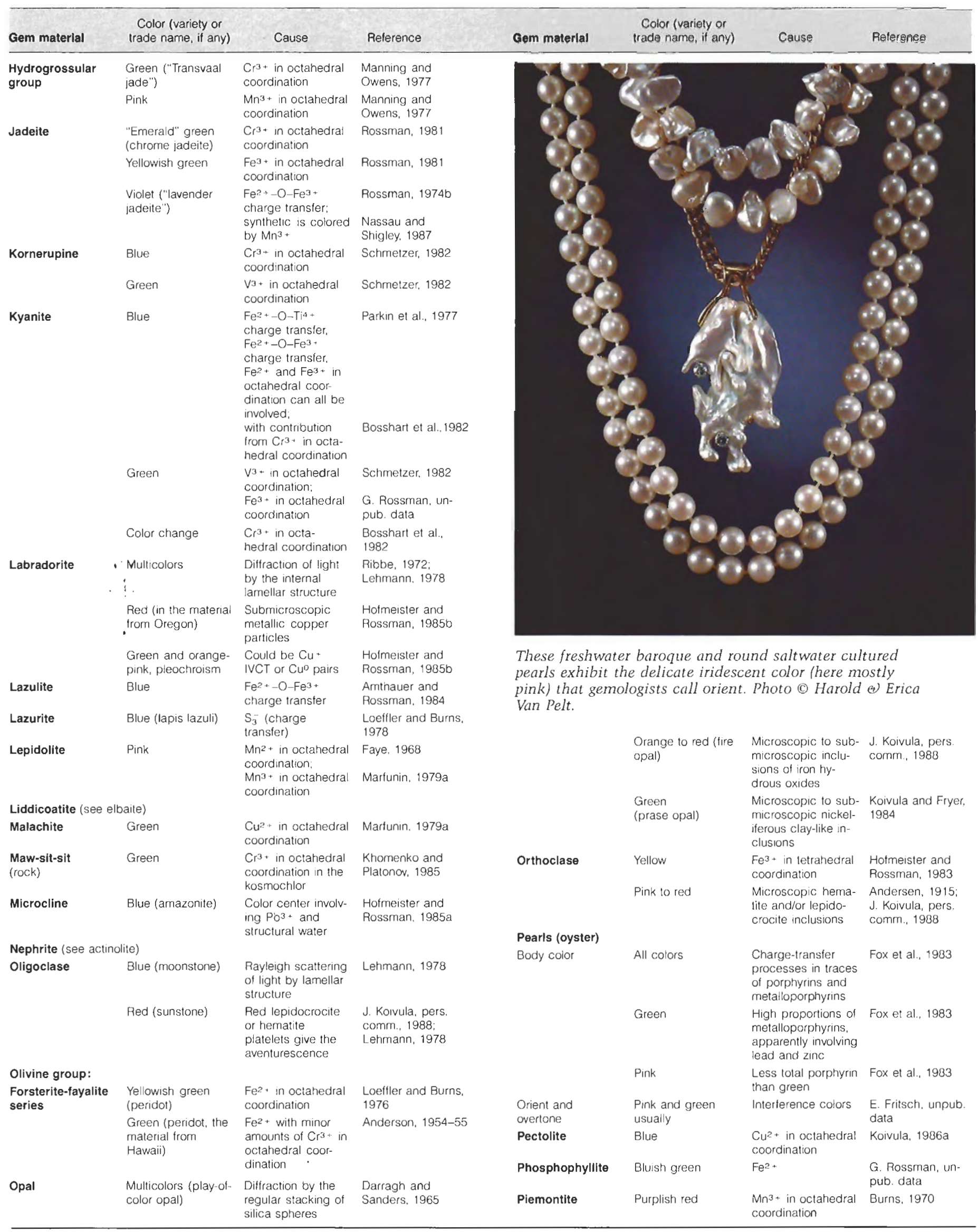




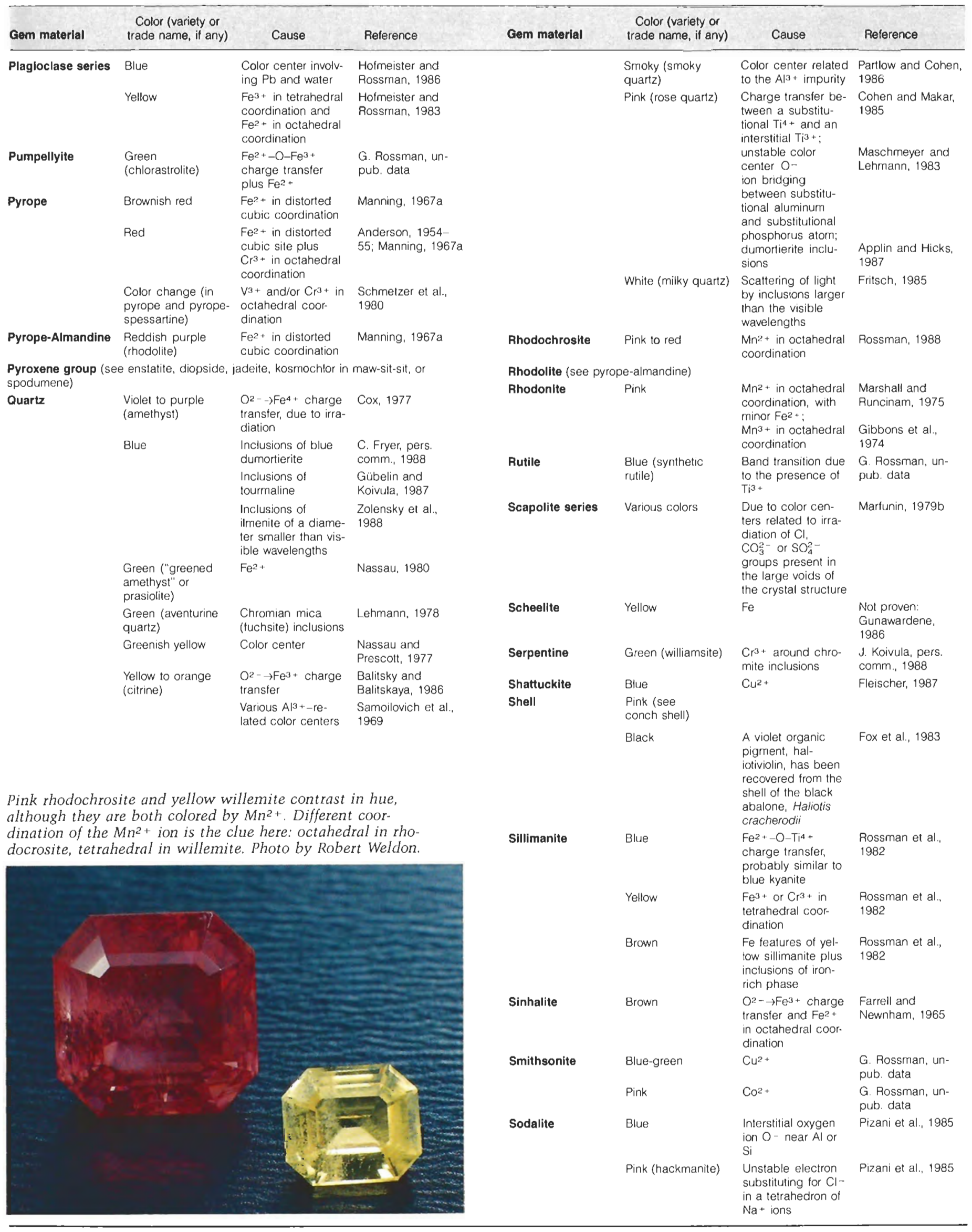




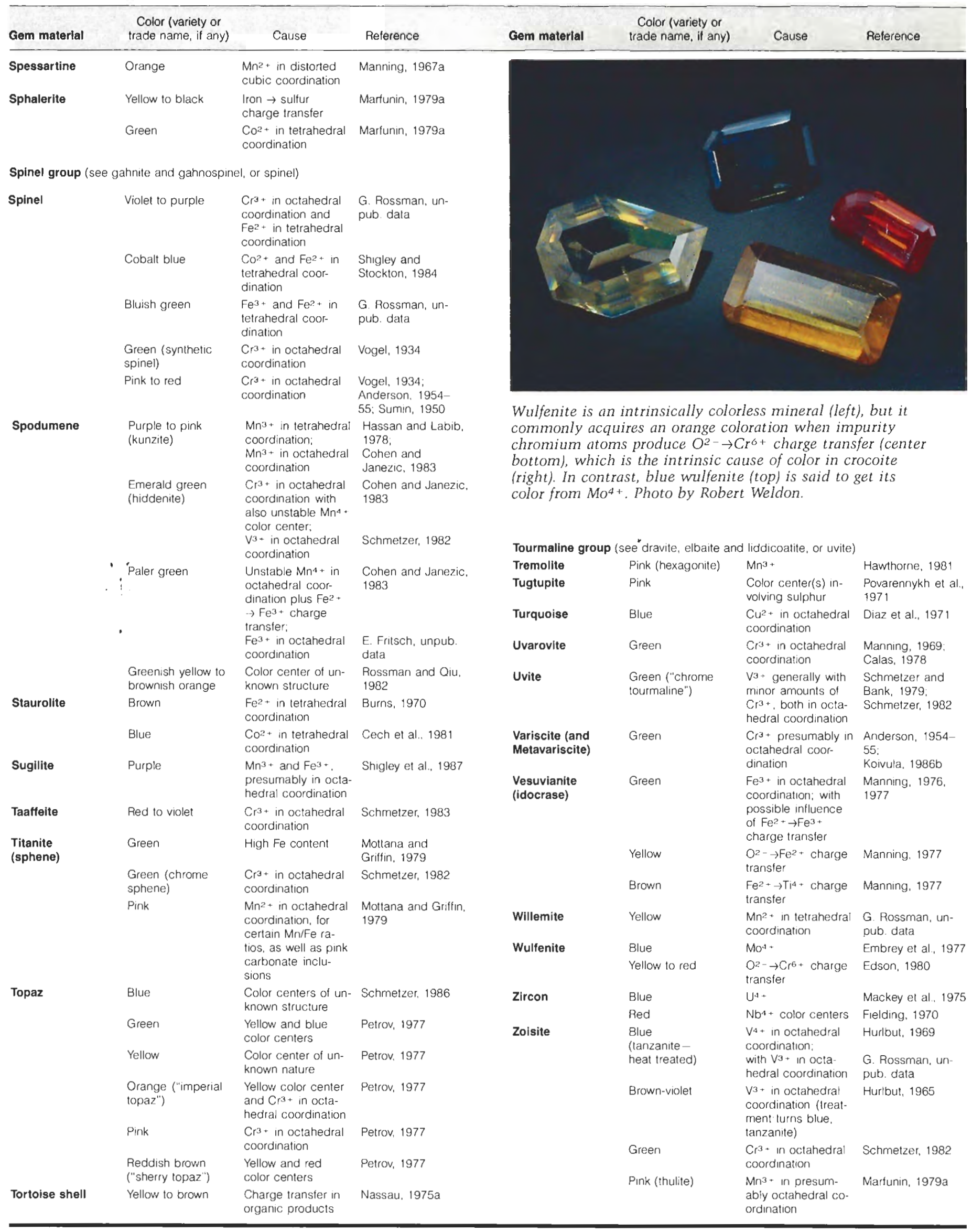




\section{REFERENCES}

Abou-Eid R.M. (1976) Absorption spectra of transition metal bearing minerals at high pressure. In R. J. G. Strens, Ed., The Physics and Chemistry of Minerals and Rocks, John Wiley \& Sons, New York, pp. 641-675.

Amthauer G., Rossman G.R. (1984) Mixed valence of iron in minerals with cation clusters. Physics and Chemistry of Minerals, Vol. 11, pp. 37-51.

Andersen O. (1915) On adventurine feldspar. American lournal of Science, Vol. 40, pp. 351-399.

Anderson B.W. (1954-55) The spectroscope and its applications to gemmology, parts 10 to 17 . The Gemmologist, Vol. 23, Nos. 275-282.

Andersson L.O. (1979) The difference between Maxixe beryl and Maxixe-type beryl: An electron paramagnetic resonance investigation. Journal of Gemmology, Vol. 16, No. 5, pp. 313-317.

Appel P.W., Jensen A. (1987) A new gem material from Greenland: Iridescent orthoamphibole. Gems \&) Gemology, Vol. 23, No. 1, pp. 36-42.

Applin K.R., Hicks B.D. (1987) Fibers of dumortierite in quartz. American Mineralogist, $\mathrm{Vol}, 72$, pp. 170-172.

Balitsky V.S., Balitskaya O.V. (1986) The amethyst-citrine dichromatism in quartz and its origin. Physics and Chemistry of Minerals, Vol. 13, pp. 415-421.

Bell P.M., Mao H.K., Rossman G.R. (1975) Absorption spectroscopy of ionic and molecular units in crystals and glasses. In C. Karr, Jr., Ed., Infrared and Raman Spectroscopy of Lunar and Terrestrial Minerals, Academic Press, New York, pp. 1-38.

Berry F.J., Vaughan D.J. (1985) Chemical Bonding and Spectroscopy in Mineral Chemistry. Chapman and Hall, New York.

Bill H., Calas G. (1978) Color centers, associated rare-earth ions and the origin of coloration in natural fluorites. Physics and Chemistry of Minerals, Vol. 3, pp. 117-131.

Bosshart G., Frank E., Hänni H.A., Barot N. (1982) Blue colorchanging kyanite from East Africa. Journal of Gemmology, Vol. 18, No. 3, pp. 205-212

Braithwaite R.S.W., Flowers W.T., Hazeldine R.N, Russel M. (1973) The cause of the colour of Blue John and other purple fluorites. Mineralogical Magazine, Vol. 39, pp. 401-4l1.

Burns R.G. (1970) Mineralogical Applications of Crystal Field Theory. Cambridge Earth Science Series, Cambridge University Press.

Calas G. (1978) Le chrome et la couleur des minèraux: Un example "pédagogique." Revue de Gemmologie a.f.g., Vol. 54, pp. 6-8.

Cech F., Povondra P., Vrana S. (1981) Cobaltoan staurolite from Zambia. Bullet in de Minéralogie, Vol. 104, pp. 526-529.

Cohen A.J., Janezic G.G. (1983) The crystal-field spectra of the $3 \mathrm{~d}^{3}, \mathrm{Cr}^{3+}$ and $\mathrm{Mn}^{4}+$ in green spodumenes. In The Significance of Trace Elements in Solving Petrogenetic Problems and Controversies, Theophrastus Publications, Athens, Greece.

Cohen A.J., Makar L.N. (1985) Dynamic biaxial absorption spectra of $\mathrm{Ti}^{3+}$ and $\mathrm{Fe}^{2+}$ in a natural rose quartz crystal. Mineralogical Magazine, Vol. 49, pp. 709-715.

Collins A.T. (1982) Colour centres in diamond. Journal of Gemmology, Vol. 18, No. 1, pp. 37-75.

Cottrant J.-F., Calas G. (1981) Etude de la coloration de quelques diamants du Museum d'Histoire Naturelle. Revue de Gemmologie a.f.g., No. 67, pp. 2-5.

Cox R.T. (1977) Optical absorption of the $\mathrm{d}^{4}$ ion $\mathrm{Fe}^{4+}$ in pleochroic amethyst quartz. Journal of Physics, Vol. ClO, pp. 4631-4643.

Darragh P.J., Sanders J.V. (1965) The origin of colour in opal. Australian Gemmologist, No. 46, pp. 9-12.

De Camargo M.B., Isotani S. (1988) Optical absorption of natural and irradiated pink tourmaline. American Mineralogist, Vol. 73, pp. 172-180

Délé-Dubois M.-L., Merlin I.-C. (1981) Etude par spectroscopie Raman de la pigmentation du squelette calcaire du corail. Revue de Gemmologie a.f.g., No. 68, pp. 10-13.

Diaz J., Farach H.A., Poole C.P. Jr. (1971) An electron spin resonance and optical study of turquoise. American Mineralogist, Vol. 56, pp. 773-781.

Dickson B.L., Smith G. (1976) Low temperature optical absorption and Mossbauer spectra of staurolite and spinel. Canadian Mineralogist, Vol. 14, pp. 206-215.

Dietrich R.V. (1985) The Tourmaline Group. Von Nostrand Reinhold Co., New York.

Dowty E. (1971) Crystal chemistry of titanian and zirconian garnet: I. Review and spectral studies. American Mineralogist, Vol. 56, pp. 1983-2009.

Edson G.M. (1980) The Red Cloud mine, Yuma County Arizona. Mineralogical Record, Vol. 11, No. 3, pp. $141-152$.

Embrey P.G., Dunn P.J., Clark A.M. (1977) Blue wulfenite from Tsumeb. Mineralogical Record, Vol. 8, No. 3, pp. 86-87.

Farrell E.F., Newnham R.E. (1965) Crystal field spectra of chrysoberyl, alexandrite, peridot and sinhalite. American Mineralogist, Vol. 50, pp. 1972-1981.

Faye G.H. (1968) The optical absorption spectra of certain transition metal ions in muscovite, lepidolite and fuchsite. Canadian Journal of Earth Sciences, Vol. 5, pp. 31-38.

Faye G.H. (1972) Relationship between crystal field splitting parameter " $\Delta_{\mathrm{VI}}$ " and $\mathrm{M}_{\mathrm{host}} \mathrm{O}$ bond distance as an aid in the interpretation of absorption spectra of $\mathrm{Fe}^{2+}$-bearing materials. Canadian Mineralogist, Vol. 11, pp. 473-487.

Faye G.H., Manning P.G., Nickel E.H. (1968) The polarized optical absorption spectra of tourmaline, cordierite, chloritoid and vivianite: ferrous-ferric electronic interaction as a source of pleochroism. American Mineralogist, Vol. 53, pp. 1174-1201.

Ferguson J., Fielding P.E. (1971) The origins of the colours of yellow, green and blue sapphires. Chemical Physics Let ters, Vol. 10, No. 3, pp. 262-265.

Fielding P.E. (1970) The distribution of uranium, rare earths, and color centers in a crystal of natural zircon. American Mineralogist, Vol. 55, pp. 428-440.

Fleischer M. (1987) Glossary of Mineral Species, 5th ed. Mineralogical Record, Inc., Tucson, AZ.

Fox D.L., Brown F.A., Losey G.S. (1983) Coloration, biological. New Encyclopedia Brittanica, Encyclopedia Brittanica Chicago, IL, pp. 911-929.

Fritsch E. (1985) La couleur des minéraux et des gemmes: Des couleurs du diamant aux étoiles du saphir. Monde et) Minéraux, No. 70, pp. 12-22.

Fritsch E., Rossman G.R. (1987) An update on color in gems Part 1: Introduction and colors caused by dispersed metal ions. Gems e Gemology, Vol. 23, No. 3, pp. 126-139.

Fritsch E., Rossman G.R. (1988) An update on color in gems. Part 2: Colors involving multiple atoms and color centers. Gems \&) Gemology, Vol. 24, No. 1, pp. 3-15.

Gibbons R.V., Ahrens T.J., Rossman G.R. (1974) A spectrographic interpretation of shock-produced color change in rhodonite $\left(\mathrm{MnSiO}_{3}\right)$ : The shock-induced reduction of $\mathrm{Mn}$ (III) to $\mathrm{Mn}(\mathrm{II})$. American Mineralogist, Vol. 59, pp. $177-182$.

Goldman D.S., Rossman G.R., Dollase W.A. (1977) Channel constituents in cordierite. American Mineralogist, Vol. 62, pp. 1144-1157.

Goldman D.S., Rossman G.R., Parkin K.M. (1978) Channel constituents in beryl. Physics and Chemistry of Minerals, Vol. 3, pp. 225-235.

Gübelin E.J. (1975) The Color Treasury of Gemstones. Elsevier 
Phaidon, London.

Gübelin E.J., Koivula J.I. (1987) Photoatlas of Inclusions in Gemstones, ABC Edition, Zurich.

Gübelin E.J., Weibel M. (1975) Green vanadium grossular garnet from Lualenyi, near Voi, Kenya. Lapidary Journal, Vol. 29, pp. $402-426$.

Gunawardene M. (1986) Colombage-Ara scheelite. Gems e) Gemology, Vol. 22, No. 3, pp. 166-169.

Hassan F, Labib M. (1978) Induced color centers in $\alpha$-spodumene called kunzite. Neues Jahrbuch für Mineralogie, Abhandlungen, Vol. 134, No. 1, pp. 104-115.

Harder H. (1969) Farbgebende Spurenelemente in den natürlichen Korunden. Neues Jahrbuch für Mineralogie, Abhandlungen, Vol. 110, pp. 128-141.

Haw thorne F. \{1981\} Amphibole spectroscopy. In D. R. Veblen, Ed., Reviews in Mineralogy, Vol. 9A: Amphiboles and Other Hydrous Pyriboles - Mineralogy, Mineralogical Society of America, Washington, DC, pp, 103-137.

Hirai H., Nakazawa H. (1982) Origin of iridescence in garnet: An optical interference study. Physics and Chemistry of Minerals, Vol. 8, pp. 25-28.

Hofmeister A.M., Rossman G.R. \{1983\} Colors in feldspars. In P. H. Ribbe, Ed., Reviews in Mineralogy, Vol. 2, 2nd ed.: Feldspar Minerals, Mineralogical Society of America, Washington, DC, pp. 271-280

Hofmeister A.M., Rossman G.R. (1985a) A spectroscopic study of irradiation coloring of amazonite: Structurally hydrous, Pb-bearing feldspar. American Mineralogist, Vol. 70, pp. 794-804

Hofnieister A.M., Rossman G.R. (1985b) Exsolution of netallic copper from Lake County labradorite. Geology, Vol. 13, pp. 644-647.

Hofmeister 'A.F., Rossman G.R. (1986) A spectroscopic study of blue radiation coloring plagioclase. American Mineralogist, Vol. 71, pp. 95-98.

Hurlbut C.S. (1969) Gem zoisite from Tanzania. American Mineralogist, Vol. 54, pp. 702-709.

Khomenko V.M., Platonov A.N. \{1985\} Electronic absorption spectra of $\mathrm{Cr}^{3+}$ ions in natural clinopyroxenes. Physics and Chemistry of Minerals, Vol. 11, pp. 261-265.

Koivula J.I. (1986a) Gem news: Pectolite. Gems \&) Gemology, Vol. 22, No. 3, pp. 187-188.

Koivula J.I. (1986b) Gem news: Metavariscite. Gems Gemology, Vol. 22 , No. 4 , pp. 247-248.

Koivula J.I. (1987) Gem news: lridescent andradite garnets. Gems e) Genology, Vol. 23, No. 3, pp. 173-175.

Koivula J.1., Fryer C.W. (1984) Green opal from East Africa. Gems a) Gemology, Vol. 20, No. 4, pp. 226-227.

Lehmann G. (1978) Farben von Mineralen [sic] und ihre Ursachen. Fortschritte der Mineralogie, Vol. 56, No. 2, pp. 172-252.

Loeffler B.M., Burns R.G. (1976) Shedding light on the color of gems and minerals. American Scientist, Vol. 64, pp. $636-647$.

Lowther J.E. (1984) The form of different charge states of the vacancy in diamond. Journal of Physics and Chemistry of Solids, Vol. 45, pp. 127-131.

Mackey D.J., Runcinam W.A., Vance E.R. (1975) Crystal-field calculations for energy levels of $\mathrm{U}^{4+}$ in $\mathrm{ZrSiO}_{4}$. Physical Review B, Vol. 11, pp. 211-218.

Manning P.G. (1967a) The optical absorption spectra of the garnets almandine-pyrope, pyrope and spessartine and some structural interpretations of mineralogical significance. Canadian Mineralogist, Vol. 9, pp. 237-25l.

Manning P.G. (1967b) The optical absorption spectra of some andradite and the identification of the ${ }^{6} A_{1} \rightarrow{ }^{4} A_{1}{ }^{4} E(G)$ transition in octahedrally bonded $\mathrm{Fe}^{3+}$. Canadian Journal of Earth Sciences, Vol. 4, pp. 1039-1047.

Manning P.G. (1969) Optical absorption studies of grossular, andradite (var. colophonite) and uvarovite. Canadian Mineralogist, Vol. 9, pp. 723-729.

Manning P.G. (1970) Racah parameters and the relationship to lengths and covalence of $\mathrm{Mn}^{2+}$ - and $\mathrm{Fe}^{3+}$-oxygen bonds in silicates. Canadian Mineralogist, Vol. 10, pp. 677-688.

Manning P.G. (1972) Optical absorption spectra of $\mathrm{Fe}^{3+}$ in octahedral and tetrahedral sites in natural garnets. Cana dian Mineralogist, Vol. 11, pp. 826-839.

Manning P.G. (1973) Effect of second nearest-neighbour interaction on $\mathrm{Mn}^{3}+$ absorption in pink and black tourmaline. Canadian Mineralogist, Vol. 11, pp. 97 I-977.

Manning P.G. (1976) Ferrous-ferric interaction on adjacent facesharing antiprismatic sites in vesuvianite: Evidence for ferric iron in eight coordination. Canadian Mineralogist, Vol. 14, pp. 216-220.

Manning P.G. (1977) Charge transfer interaction and the origin of color in brown vesuvianite. Canadian Mineralogist, Vol. 15, pp. 508-511.

Manning P.G., Owens D.R. (1977) Electron microprobe, X-ray diffraction, and spectral studies of South African and British Columbian "jades." Canadian Mineralogist, Vol. 15 , pp. 512-517.

Manson D.V., Stockton C.M. (1982) Gem-quality grossular garnets. Gems (4) Gemology, Vol. 18, No. 4, pp. 204-213.

Marfunin A.S. (1979a) Physics of Minerals and Inorganic Materials, An Introduction. Trans. by N. G. Egorova and A. G. Mishchenko, Springer Verlag, Berlin.

Marfunin A.S. (1979b) Spectroscopy, Luminescence and Radiation Centers in Minerals. Trans. by V. V. Schiffer, Springer Verlag, Berlin.

Marshall M., Runcinam W.A. (1975) The absorption spectrum of rhodonite. American Mineralogist, Vol. 60, pp. 88-97.

Maschmeyer D., Lehmann G. (1983) A trapped-hole center causing rose coloration of natural quartz. Zeitschrift für Kristallographie, Vol. 163, pp. 181-196.

Mattson S.M., Rossman G.R. (1984) Ferric iron in tourmaline. Physics and Chemistry of Minerals, Vol. 11, pp. 225-234.

Mattson S.M., Rossman G.R. (1987) Identifying characteristics of charge transfer transitions in minerals. Physics and Chemistry of Minerals, Vol. 14, pp. 94--99.

Moore R.K., White W.B. (1971) Intervalence electron transfer effects in the spectra of the melanite garnets. American Mineralogist, Vol. 56, pp. 826-840.

Mottana A., Griffin W.L. (1979) Pink titanite (greenovite) from St. Marcel, Valle D'Aosta, Italy. Rendiconti Societa Italiana di Mineralogia e Petrologia, Vol, 35, pp. 135-143.

Nassau K. (1975a) The origin of color in gems and minerals. Part 2. Gems e) Gemology, Vol. 15, No. 1, pp. 2-11.

Nassau K. (1975b) The origin of color in gems and minerals. Part 3. Gents 4 Gemology, Vol. 15, No. 2, pp. 34-43.

Nassau K. (1980) Gems Made by Man. Chilton Book Co., Radnor, PA.

Nassau K. (1983) The Physics and Chemistry of Color: The Fifteen Causes of Color. John Wiley \& Sons, New York.

Nassau K. (1984) Gemstone Enhancement. Butterworths, Stoneham, MA.

Nassau K., Prescott E. (1977) Smoky, blue, greenish yellow and other irradiation-related colors in quartz. Mineralogical Magazine, Vol. 41, pp. 301-312.

Nassau K., Shigley J.E. (1987) A study of the General Electric synthetic jadeite. Gems «) Gemology, Vol. 23, No. 1, pp. $27-35$.

Nassau K., Valente G.K. (1987) The seven types of yellow sapphire and their stability to light. Gems 4 Gemology, Vol. 23, No. 4, pp. 222-231.

parkin K.M., Loeffler B.M., Burns R.G. (1977) Mossbauer spectra of kyanite, aquamarine, and cordierite showing intervalence charge transfer. Physics and Chemistry of Minerals, Vol. 1, pp. 301-311. 
Partlow D.P., Cohen A.J. (1986) Optical studies of biaxial Alrelated color centers in smoky quartz. American Mineralogist, Vol. 71, pp. 589-598.

Petrov I. (1977) Farbuntersuchungen an Topas. Neues Jahrbuch für Mineralogie Abhandlungen, Vol. 130, No. 3, pp. 288-302.

Pizani P.S., Terrile M.C., Farach H.A., Poole C.P. Jr. (1985) Color centers in sodalite. American Mineralogist, Vol. 70, pp. $1186-1192$.

Povarennykh A.S., Platonov A.N., Tarashchan A.N., Belichenko V. P. (1971) The colour and luminescence of tugt upite (beryllosodalite) from Ilimaussaq, South Greenland. Meddelelser om Gronland, Vol. 181, pp. 1-12.

Pye L.D., O'Keefe J.A., Freéchette V.D., Eds. [1984] Natural Glasses. North Holland Publishing, Amsterdam.

Ribbe P.H. (1972) Interference colors in oil slicks and feldspars. Mineralogical Record, Vol. 3, pp. 18-22.

Rolandi V. (1981) Les gemmes du regne animal: Etude gemmologique des sécrétions des Cnidaires. Revue de Gemmologie a.f.g., Vol. 66, pp. 3-9.

Rossman G.R. (1974a) Optical spectroscopy of green vanadium apophyllite from Poona, India. American Mineralogist, Vol. 59, pp. 621-622.

Rossman G.R. (1974b) Lavender jade. The optical spectrum of $\mathrm{Fe}^{3+}$ and $\mathrm{Fe}^{2+}-\mathrm{Fe}^{3+}$ intervalence charge transfer in jadeite from Burma. American Mineralogist, Vol. 59, pp. 868-870.

Rossman G.R. (1980) Pyroxene spectroscopy. In C. T. Prewitt, Ed., Reviews in Mineralogy, Vol, 7: Pyroxenes, Mineralogical Society of America, Washington, DC, pp. 93-113.

Rossman G.R. (1981) Color in gems: The new technologies. Gems \&emology, Vol, 17, No. 2, pp. 60-71

Rossman G.R. (1988) Optical spectroscopy. In F. C. Hawthorne, Ed., Reviews in Mineralogy, Vol. 18: Spectroscopic Methods in Mineralogy and Geology, Mineralogical Society of America, Washington, DC, pp. 207-254.

Rossman G.R., Mattson S.M. (1986) Yellow, manganese-rich elbaite with manganese-titanium intervalence charge transfer. American Mineralogist, Vol. 71, pp. 599-602.

Rossman G.R., Qiu Y. (1982) Radioactive irradiated spodumene. Gems \&emology, Vol. 18, No. 2, pp. 87-90.

Rossman G.R., Grew E.S., Dollase W.A. (1982) The colors of sillimanite. American Mineralogist, Vol. 67, pp. 749-761.

Samoilovich M.I., Tsinober L.I., Kreishop V.N. (1969) The nature of radiation-produced citrine coloration in quartz. Soviet Physics-Crystallography, Vol. 13, pp. 626-628.

Schiffmann C.A. (1981) Unstable colour in a yellow sapphire from Sri Lanka. Journal of Gemmology, Vol. 17, No. 8, pp. 615-618.

Schlee D. (1984) Ungewöhnliche Farbvarianten des Baltischen Bernsteins: Blau, grau, orange und "gold" als Folge von Rissesystemen. Bernstein-Neuigkeiten, Stuttgarter Beiträge zur Naturkunde, Series C, No. 18, pp. 2-8.

Schmetzer K. (1982) Absorptionsspektroskopie und Farbe von $\mathrm{V}^{3+}$-haltigen natürlichen Oxiden und Silikaten-ein Beitrag zur Kristallchemie des Vanadiums. Neues Jahrbuch für Mineralogie, Abhandlungen, Vol. 144, pp. 73-106.

Schmetzer K. (1983) Crystal chemistry of natural Be-Mg-AIoxides: Taaffeite, taprobanite, musgravite. Neues Jahrbuch für Mineralogie, Abhandlungen, Vol. 146, pp. 15-28.

Schmetzer K. (1986) Färbung und Bestrahlungschaden in elektronenbestrahlten blauen Topasen. Zeitschrift der Deutschen Gemmologischen Gesellschaft, Vol. 35, No. 1/2, pp. 27-38.
Schmetzer K. (1987) Zur Deutung der Farbursache blauer Saphire-eine Diskussion. Neues Jahrbuch für Mineralogie, Monatshefte, No. 8, pp. 337-343.

Schmetzer K., Bank H. (1979) East African tourmalines and their nomenclature. Journal of Gemmology, Vol. 16, pp. 310-311.

Schmetzer K., Bank H. (1981) The colour of natural corundum. Neues lahrbuch für Mineralogie, Monatshefte, Vol. 11, No. 2, pp. 59-68.

Schmetzer K., Bank H., Gübelin E. (1980) The alexandrite effect in minerals: Chrysoberyl, garnet, corundum, fluorite. Neues Jahrbuch für Mineralogie, Abhandlungen, Vol. 138, pp. 147-164.

Schmetzer K., Bosshart G., Hänni H.A. (1982) Naturfarbene und behandelte gelbe und orange braune Sapphire. Zeitschrift der Deutschen Gemmologischen Gesellschaft, Vol. 31, No. 4, pp. 265-279.

Schmetzer K., Bosshart G., Hänni H.A. (1983) Naturallycoloured and treated yellow and orange brown sapphires. Journal of Gemmology, Vol. 18, No. 7, pp. 607-621.

Shigley J.E., Foord E.E. (1984) Gem-quality red beryl from the Wah-Wah Mountains, Utah. Gems \&) Gemology, Vol. 20, No. 4, pp. 208-221.

Shigley J.E., Koivula J.I. (1985) Amethystine chalcedony. Gems (4) Gemology, Vol. 21, No. 4, pp. 219-223.

Shigley J.E., Koivula J.1., Fryer C.W. (1987) The occurrence and gemological properties of Wessels Mine sugilite. Gems \&? Gemology, Vol. 23, No. 2, pp 78-90.

Shigley J.E., Stockton C.M. (1984) "Cobalt-blue" gem spinels. Gems (4) Gemology, Vol. 20, No. 1, pp. 34-41.

Smith G. (1977) Low temperature optical studies of metal-metal charge transfer transitions in various minerals. Canadian Mineralogist, Vol. 10, pp. 500-507.

Smith G., Strens R.G.J. (1976) Intervalence transfer absorption in some silicate, oxide and phosphate minerals. In R. G. J. Strens, Ed., The Physics and Chemistry of Minerals and Rocks, John Wiley \& Sons, New York, pp. 583-612.

Smith G., Hålenius U., Langer K. (1982) Low temperature spectral studies of $\mathrm{Mn}^{3+}$-bearing andalusite and epidote type minerals in the range $30000-5000 \mathrm{~cm}^{-1}$. Physics and Chemistry of Minerals, Vol. 8, pp. 136-142.

Stockton C.M., Manson D.V. (1983) Gem andradite garnets. Gems $\Theta$ Gemology, Vol. 19, No. 4, pp. 202-208.

Stockton C.M., Manson D.V. (1984) Editorial forum: "Fine green" demantoids. Gems \& Gemology, Vol. 20, No. 3, p. 179.

Sumin N.G. (1950) Accessory elements in spinels. Trudy Mineralog. Museya, Akad. Nauk S.S.S.R., No. 2, pp. $113-123$.

Vogel P. (1934) Optische Untersuchungen am Smaragd und einigen anderen durch Chrom gefärbten Mineralien. Neues lahrbuch für Mineralogie, Geologie und Paleontologie, Vol. A68, pp. 401-438.

Webster R., rev. by B. W. Anderson (1983) Gems, Their Sources, Descriptions and Identification, 4th ed. Butterworths, London.

Wood D.L., Nassau K. (1968) The characterization of beryl and emerald by visible and infrared absorption spectroscopy. American Mineralogist, Vol. 53, pp. 777-800.

Zolensky M.E., Sylvester P.J., Paces J.B. (1988) Origin and significance of blue coloration in quartz from Llano rhyolite (Ilanite), north-central Llano County, Texas. American Mineralogist, Vol. 73, pp. 313-323. 